\title{
Therapeutic Effects and Safe Uses of Plant-Derived Polyphenolic Compounds in Cardiovascular Diseases: A Review
}

\author{
Badriyah Shadid Alotaibi ${ }^{1}$ \\ Munazza ljaz ${ }^{2}$ \\ Manal Buabeid (iD) 3,4 \\ Zelal Jaber Kharaba ${ }^{5}$ \\ Hafiza Sidra Yaseen ${ }^{6}$ \\ Ghulam Murtaza (iD ${ }^{6}$ \\ 'Department of Pharmaceutical Sciences, \\ College of Pharmacy, Princess Nourah \\ Bint Abdulrahman University, Riyadh, \\ Saudi Arabia; ${ }^{2}$ Institute of Molecular \\ Biology and Biotechnology, The \\ University of Lahore, Lahore, Pakistan; \\ ${ }^{3}$ Medical and Bio-Allied Health Sciences \\ Research Centre, Ajman University, \\ Ajman, United Arab Emirates; \\ ${ }^{4}$ Department of Clinical Sciences, Ajman \\ University, Ajman, 346, United Arab \\ Emirates; ${ }^{5}$ Department of Clinical \\ Sciences, College of Pharmacy, Al-Ain \\ University of Science and Technology, \\ Abu Dhabi, United Arab Emirates; \\ ${ }^{6}$ Department of Pharmacy, COMSATS \\ University Islamabad, Lahore Campus, \\ Lahore, 54000, Pakistan
}

\begin{abstract}
Polyphenols have long been recognized as health-promoting entities, including beneficial effects on cardiovascular disease, but their reputation has been boosted recently following a number of encouraging clinical studies in multiple chronic pathologies, that seem to validate efficacy. Health benefits of polyphenols have been linked to their well-established powerful antioxidant activity. This review aims to provide comprehensive and up-to-date knowledge on the current therapeutic status of polyphenols having sufficient heed towards the treatment of cardiovascular diseases. Furthermore, data about the safety profile of highly efficacious polyphenols has also been investigated to further enhance their role in cardiac abnormalities. Evidence is presented to support the action of phenolic derivatives against cardiovascular pathologies by following receptors and signaling pathways which ultimately cause changes in endogenous antioxidant, antiplatelet, vasodilatory, and anti-inflammatory activities. In addition, in vitro antioxidant and pre-clinical and clinical experiments on antiinflammatory as well as immunomodulatory attributes of polyphenols have revealed their role as cardioprotective agents. However, an obvious shortage of in vivo studies related to dose selection and toxicity of polyphenols makes these compounds a suitable target for clinical investigations. Further studies are needed for the development of safe and potent herbal products against cardiovascular diseases. The novelty of this review is to provide comprehensive knowledge on polyphenols safety and their health claims. It will help researchers to identify those moieties which likely exert protective and therapeutic effects towards cardiovascular diseases.
\end{abstract}

Keywords: cardiovascular diseases, polyphenols, clinical trials, cardioprotective, antioxidant

\section{Introduction}

In recent years, the excessive modification in lifestyles of inhabitants across the world has moved human civilizations from a natural diet to unhealthy foods and physical inactivity. ${ }^{1}$ The grouping of such a lifestyle with continuous consumption of toxic substances such as alcohol, cigarettes, and drug abuse has elevated the risk of cardiovascular diseases (CVDs). ${ }^{2}$ Cardiovascular maladies majorly affect the "blood circulatory system" and involve the heart as well as blood vessels. This multifactorial disorder is classified as coronary heart disease, cerebrovascular disease, peripheral arterial disease, rheumatic heart disease, congenital heart disease, deep vein thrombosis, and pulmonary embolism (Table 1). ${ }^{3}$ Moreover, these noncommunicable CVDs conditions may lead to various complications such as heart
Correspondence: Manal Buabeid;

Ghulam Murtaza

Tel +923215129950

Fax +92 992-38344I

Email m.buabeid@ajman.ac.ae;

gmdogar356@gmail.com 


\section{Graphical Abstract}

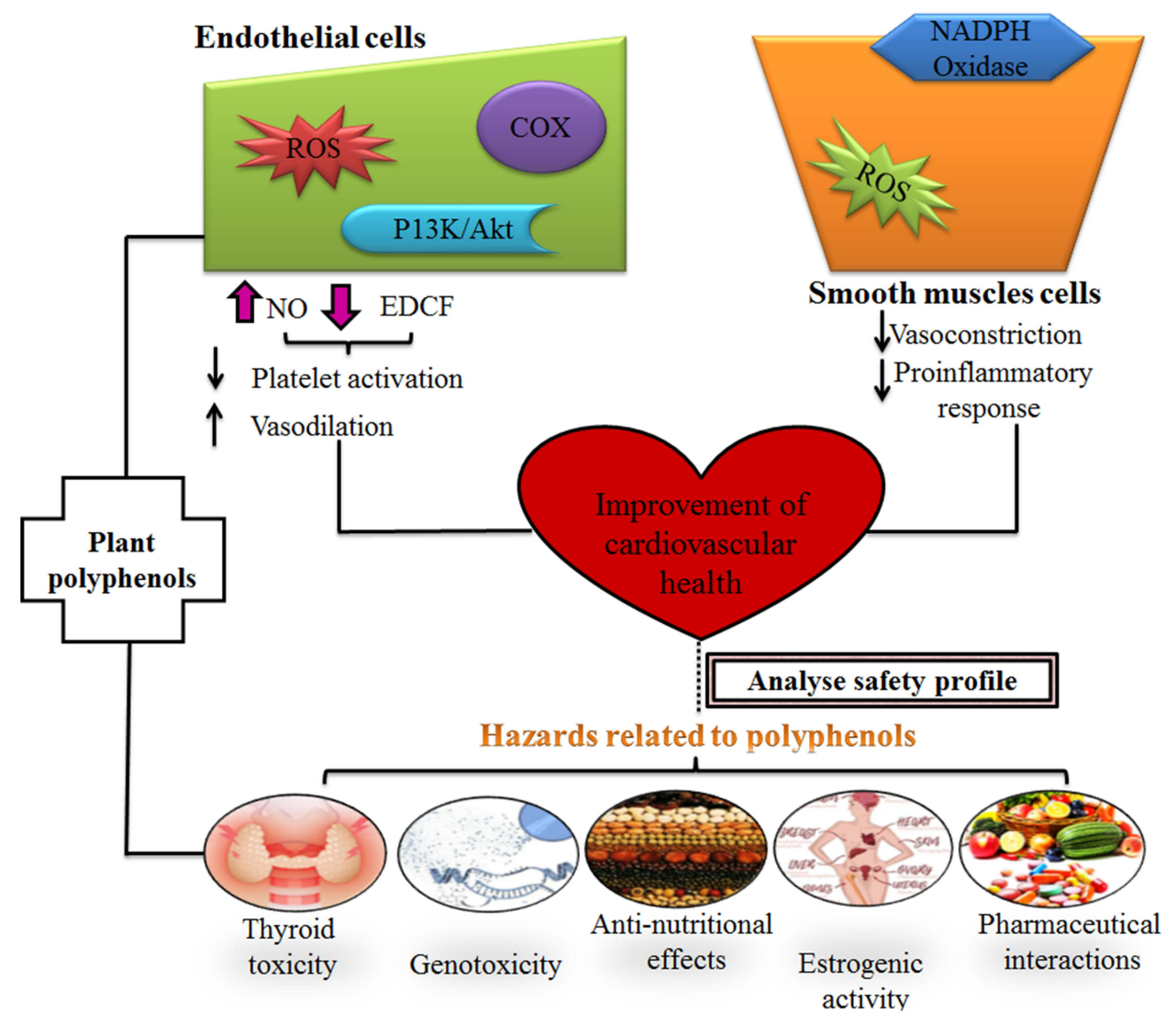

stroke, myocardial infarction, ischemia, angina, atherosclerosis, arrhythmia, and heart failure. ${ }^{4}$ According to the World Health Organization (WHO), the most common cause of increased mortality rate is "cardiovascular diseases" around the globe. ${ }^{5}$ According to the WHO, an estimation in 2016 showed that almost 17.9 million people died annually due to CVSDs, which is around $31 \%$ of global deaths and, out of it, $85 \%$ are just because of

Table I Topology and a Brief Description of CVDs

\begin{tabular}{|c|c|c|c|}
\hline Disease Name & Pathological Mechanism & Risk Factors & References \\
\hline $\begin{array}{l}\text { Coronary heart } \\
\text { disease } \\
\text { or coronary } \\
\text { artery disease }\end{array}$ & $\begin{array}{l}\text { Narrowing of coronary arteries due to fatty deposits, } \\
\text { which limits blood flow to cardiac myocytes. }\end{array}$ & $\begin{array}{l}\text { Atherosclerosis, unhealthy food, lack of exercise, } \\
\text { and smoking }\end{array}$ & {$[101,104]$} \\
\hline $\begin{array}{l}\text { Cerebrovascular } \\
\text { disease }\end{array}$ & $\begin{array}{l}\text { Brain cells do not get enough oxygen and ischemic } \\
\text { stroke or embolism may result }\end{array}$ & $\begin{array}{l}\text { Comorbidities (Hypertension, Obesity, Diabetes } \\
\text { mellitus, Hypercholesterolemia), poor diet, } \\
\text { tobacco usage }\end{array}$ & {$[72]$} \\
\hline $\begin{array}{l}\text { Rheumatic heart } \\
\text { disease }\end{array}$ & Damage of heart valves due to rheumatic fever & Untreated streptococcal infections & [87] \\
\hline $\begin{array}{l}\text { Congenital heart } \\
\text { disease }\end{array}$ & $\begin{array}{l}\text { Defect present at birth in hearts walls, valves, and blood } \\
\text { vessel in the supply of blood to the heart and whole } \\
\text { body }\end{array}$ & Alcohol abuse, smoking, chromosomal defects & {$[104]$} \\
\hline
\end{tabular}


cardiac stroke and heart failure. ${ }^{6}$ Three years ago, statistical data of WHO revealed 250,000 deaths annually in Pakistan due to heart stroke and heart failure, and this was $19 \%$ of global mortalities. ${ }^{7}$ However, an alarming increase in CVD cases has been observed in Pakistan in 2019, and WHO found a whopping increase of $29 \%$ of total deaths, which is almost 406,870 per year and expected to increase to 22.2 million by $2030{ }^{2,8}$

Several epidemiological reports have exhibited that lower- and middle-income countries mostly become a target of CVSDs due to a lack of an appropriate healthcare system. ${ }^{9}$ In addition, the WHO states that $75 \%$ of cardiovascular diseases can be prevented by addressing "behavioral risk factors" such as tobacco use, physical inactivity, unhealthy diet, obesity, lifeless attitude, stress, alcohol abuse, and obesity. ${ }^{10}$ On the other hand, the role of "non-modifiable factors" such as gender, age, ethnicity, and family history with an increased incidence of CVDs can never be overlooked. However, controversy remains to point out specific diet factors (for instance, meat, fiber, and coffee) and their relationship with cardiovascular ailments.

Pathophysiologically, clinical events of heart stroke and failure are related to any physical trauma, dyslipidemia, immunological reactions, and inflammation. ${ }^{11}$ Generally, a balance exists between the redox reaction of reactive oxygen species (ROS) and intracellular antioxidants to maintain cell signaling and vascular function. However, excessive production of ROS leads to endothelial dysfunction and changes in molecular pathways that underpin the pathogenesis of CVDs. ${ }^{12}$ ROS directly or indirectly activate different extracellular stimuli (AngII and TNF- $\alpha$ ) as well as induce hypertrophy-linked genes (c-fos, c-jun, and erg-1) which ultimately transform hypertrophic myocytes. Thus, oxidative stress is commonly an underlying mechanism provoking "myocardial diseases" and "vascular complications". 13,14 Hypertension is a hallmark of cardiac hypertrophy in response to high blood pressure and volume which predisposes to heart failure (HF) through apoptosis. ${ }^{15}$ While transient aggregation and release of platelets reflect cyclic variation in blood flow and mimics ruptured atherosclerotic plaque, a pre-requisite for acute coronary syndromes. ${ }^{16}$ Besides this, disordered calcium signaling is a common cause of cardiomyopathy and HF. ${ }^{17}$ Moreover, one more important pathogenic factor involved in the progression of cardiac hypertrophy to heart failure is "atherosclerosis"18 characterized by fatty streaks associated with fibrous plaque (combination of inflammatory cells, smooth muscle cells, and lipid components). ${ }^{19}$ Therefore, cardiovascular disease progression is indicated intracellularly through inflammatory biomarkers such as CD-40, C-reactive proteins, and cardiac myofilaments protein "troponin". ${ }^{20}$

A large number of synthetic drugs (anticoagulants, calcium channel blockers, vasodilators, angiotensinconverting enzyme inhibitors, anti-platelets drugs, cholesterol-lowering agents, ß-receptor antagonists, and cellprotein based therapies) are used to treat cardiovascular conditions but cause a serious unwanted effect on human health and are not economic, thus usage of herbal products is skyrocketing in this contemporary era. ${ }^{21}$ The WHO estimated that around $75 \%$ of the global medical market are phytomedicines. ${ }^{22}$

Medical plant research gains wide importance in the treatment of CVDs and other ailments because of their structural specificity and diversity. ${ }^{23}$ Herbal drugs are not only limited to chemical composition and pharmacology but now encompass study of "metabolites and their respective mechanism of action". In addition, herbal treatment provides a therapeutic effect as well as nutritional support due to the rich contents of phytochemicals and minerals. ${ }^{24,25}$ The overview of various articles touched on bioactive characteristics of well-tolerated phytochemicals which can be exploited for the development of potent therapeutic agents and can be added easily to an individual's diet. ${ }^{26}$ Major classes of plant-derived chemical substances (Figure 1) are alkaloids, carotenoids, flavonoids,

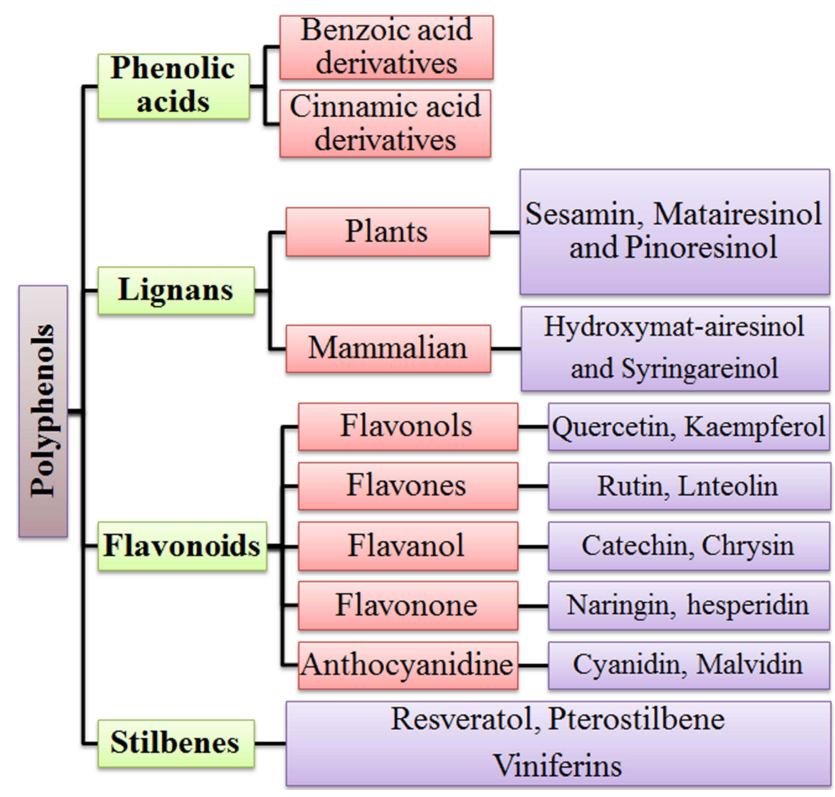

Figure I General classification of phenols. Note: Data from Singla et al. ${ }^{18}$ 
coumarins, polyphenols, saponins, terpenes, sulphur and nitrogenous compounds, carbohydrates, lipids, and proteins having an important role as cardioprotective agents. ${ }^{27}$

Besides this, discovering protected and viable medications from plants is an intriguing issue in the cardiovascular field. Most medicinal plants owning an incredible safety profile portrays them as a novel candidature for treatment of cardiovascular infections like hypertension, hyperlipidemia, atherosclerosis, and cardiac failure. ${ }^{28,29}$ Moreover, therapeutic plant-containing diets might be utilized to adequately control hypertension, for instance, adequate consumption of fruits, vegetables, nuts, red wine, coffee, and others can likewise viably forestall the event of CVD. This is related to food sources having "free radical scavenging potential". ${ }^{30}$ Additionally, therapeutic plants have antioxidant properties, making them probably an effective pharmacological agent. In therapeutic plant research for CVD, "oxidative stress restraint" is an extremely progressed research line. Multiple scientific studies recommend that flavonoids and phenolics from medical plants could diminish intracellular oxidative stress interlinked with cell-damaging. ${ }^{31}$ For examples, few preclinical studies have reported effective use of Cichorium intybus, Urtica simensis against myocardial injury or ischemia because of the presence of polyphenolic compounds. ${ }^{32}$ Furthermore, diet low in saturated fats and comprising fruits, vegetables, and essential fatty acids appear good to reduce risks of cardiovascular diseases. For instance, red yeast rice is rich in "monacolins $\mathrm{K}$ ", impedes HMGCoA reductase levels, and consequently produces a beneficial lipid lowering effect. ${ }^{33}$ There is a variety of phenolic phytochemicals which have the potential to act through different mechanisms. For instance, diosmin and hesperidin are used widely in Europe and the USA, primarily in venous insufficiency and targets cerebrospinal fluid differentiation, oxidative enzymes levels, and profibrotic molecular signals in the body. ${ }^{34}$ Polyphenols are widely distributed across the plant kingdom including fruits, cereals, vegetables, and beverages. Almost 8,000 polyphenolic compounds have been derived from natural sources until now and various other scientific studies are ongoing. ${ }^{35}$ Polyphenols are primarily classified as flavonoids, phenolic acids, lignans, and stilbenes based on a diverse number of phenol rings and other functional groups. ${ }^{36}$ Various studies have exhibited positive effects of polyphenols against cancer, inflammation, neurodegenerative, and cardiovascular diseases. For example, "pinocembrin" extracted from honey showed a profound anti- inflammatory effect through inhibition of nitric oxide, metal chelating, and upregulation of antioxidant mechanisms inside the cells. ${ }^{37}$ Moreover, two eminent flavonoids, "naringin" and "quercetin", have exerted strong antiviral, antifungal, and antiseptic effects by interfering in DNA/ RNA methylation of different viruses and bacteria. ${ }^{38}$ Several pre- and clinical studies have demonstrated the significant anti-inflammatory potential of "curcumin" and "resveratrol" flavonoids through modulation of different enzymes involved in arachidonic acid metabolism (COXI, COX-II, and phospholipase A2) and due to radical scavenging property. ${ }^{39}$ With great advances in basic redox biology, increased oxidative stress in the body triggers several metabolic syndromes (MetS) including diabetes mellitus, atherosclerosis, Alzheimer's disease, and cancer. $^{40}$ Different animal model-based studies have reported that supplementation with single/multiple polyphenolic compounds cut down fat deposition in the body by inhibiting overexpression of extracellular single kinase (ERK) 1/2, the peroxisome proliferator-activated receptor (PPRA- $\gamma$ ) adiponectin pathway, vascular endothelial growth factor (VEGF), and kinase insert domain receptor. Thus, polyphenols are potential candidates for treating metabolic diseases as well. ${ }^{41}$ On the other hand, certain polyphenolic compounds may exert toxicity and detrimental impacts on living bodies. For instance, some polyphenols showed genotoxic and carcinogenic effects result in interrupted thyroid hormone biosynthesis. ${ }^{42}$ Moreover, iso-flavones are well-known because of their "estrogenic" activity and may lean toward iron depletion through inhibition of non-heme iron absorption. Therefore, safety assessment of these secondary metabolites is an efficient approach in the selection of appropriate dose relative to their natural concentration in the body. ${ }^{43}$ Furthermore, basic challenges associated with the consumption of polyphenolic compounds are unclear best doses, possible sideeffects, and long-term toxicity, intricate interactions with pharmacological drugs, poor human evidence and clinical trials, instability, and low bioavailability. ${ }^{44,45}$

No doubt, numerous outstanding reviews on polyphenols have been published already, but the reader is referred for more in-depth information. Therefore, based on the exceptional pharmacological potential and safety profile of polyphenols, a review was designed to present a summary of plant-derived safe polyphenols which act as therapeutic moieties in this modern world. Furthermore, this review will critically evaluate different studies demonstrating the "impact of polyphenols on cardiovascular diseases" along 


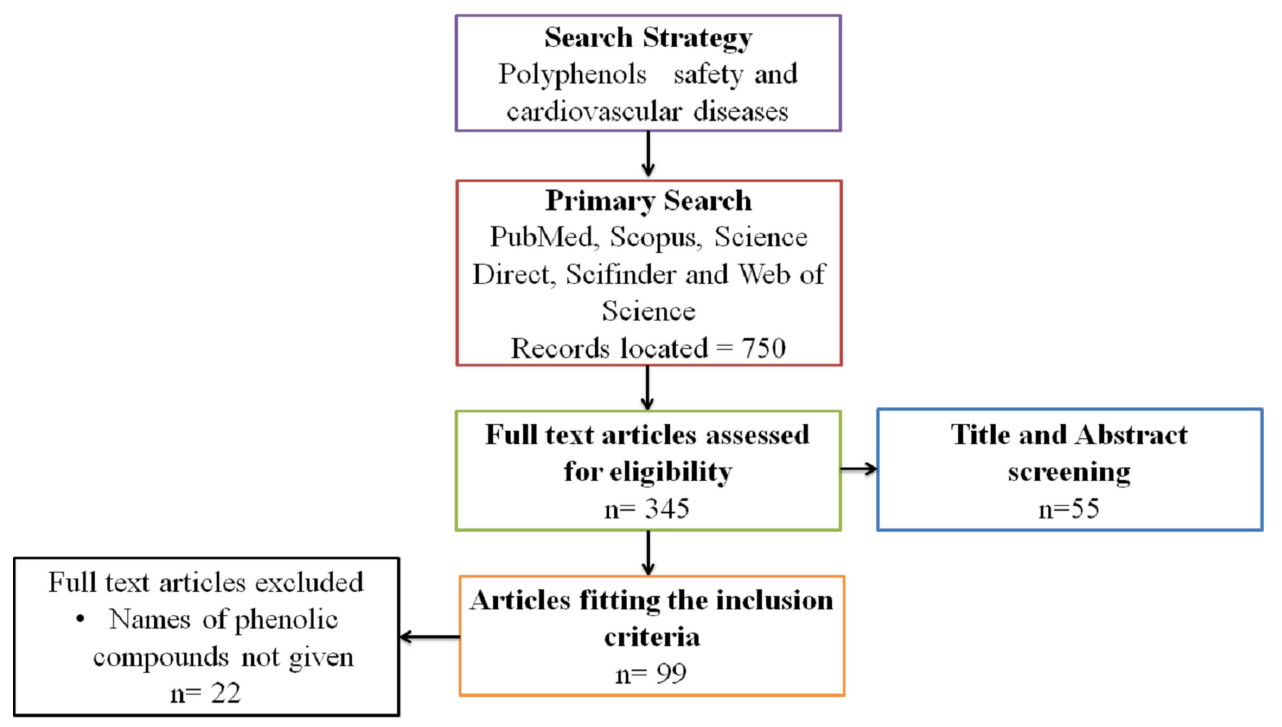

Figure 2 Flowchart summary of the systematic review process.

with their assumptive underlying mechanism in human interventions studies, animal models, and ex-vivo studies.

\section{Methodology}

A systematic review has been carried out to look at the different pharmacological properties of plant-derived phenolic compounds. To gather the information, the present review collaborated with different international databases such as Emerald Insight, Science Direct, PubMed, Web of Science, Google Scholar, Scopus, ResearchGate, and Sci-finder without limiting publication years of articles. These databases encompassed books, dissertations, patents, as well as supplementary reports and scientific journals (eg, The Lancet, Canadian Journal of Cardiology, Phytomedicine, Journal of Cardiovascular and Thoracic Research, Annals of Hepatology, Traditional Medicine and Modern World, Current Atherosclerosis Report, World Journal of Pharmaceutical Research, Cardiovascular Endocrinology and Metabolism). In addition, botanical databases such as Flora of Pakistan, The Plant List, and Flora de Brasil were also searched to confirm the botanical names of included medicinal plants. A literature search was performed using a combination of various search terms "CVS and plants", "phenols in CVS diseases", "Risk associated with phenolic compounds", "Safety of secondary metabolites", "Importance of phenols", "Clinical trials on phenolic compounds", "Primary prevention in CVDs", "Cardioprotective effect of polyphenols", "Safe dose of polyphenols in cardiovascular diseases", "Therapeutic potential of phenols", and "Phenols as drugs" to explore topic related current and previous information. The complete information was obtained from published records between the years 2000 to 2020. During the search (Figure 2), studies based on our relevant aim "safety profile of phenolic compounds and their innovative role in cardiovascular diseases" were retained only. However, non-English language publications and having irrelevant knowledge were excluded from the current study. Data and their scientific underpinning were extracted from the above sources and compared.

\section{Results and Discussion}

The present review provides the details of several epidemiological, animal, and human clinical trials-based studies on plant-sourced polyphenols in terms of their safety profile and therapeutic effect in a wide range of chronic pathologies, especially cardiovascular diseases including thrombosis, cardiac stroke, atherosclerosis, inflammation, and heart attack. Descriptive analysis of several plant extracts and isolated compounds based scientific studies was done with "Microsoft Excel Software", which showed the excellent capacity of herbs against cardiovascular diseases. Data in Figure 3 representpercentages of all species of different plants in pie-chart form. Besides this, data in Table 2 show 25 potent plants belong to different families such as Asteraceae (4 sp.), Lamiaceae (4 sp.), Apiaceae (2 sp.), Rosaceae (2 sp.), Poaceae (2 sp.), Ericaceae (1 sp.), Fabaceae (1 sp.), Punicaceae (1 sp.), Malvaceae (1 sp.), Grossulariaceae (1 sp.), Theaceae (1 sp.), Lauraceae (1 sp.), Oleaceae (1 sp.), and Vitaceae (1 sp.). Furthermore, it was also evaluated from data that plants possess 


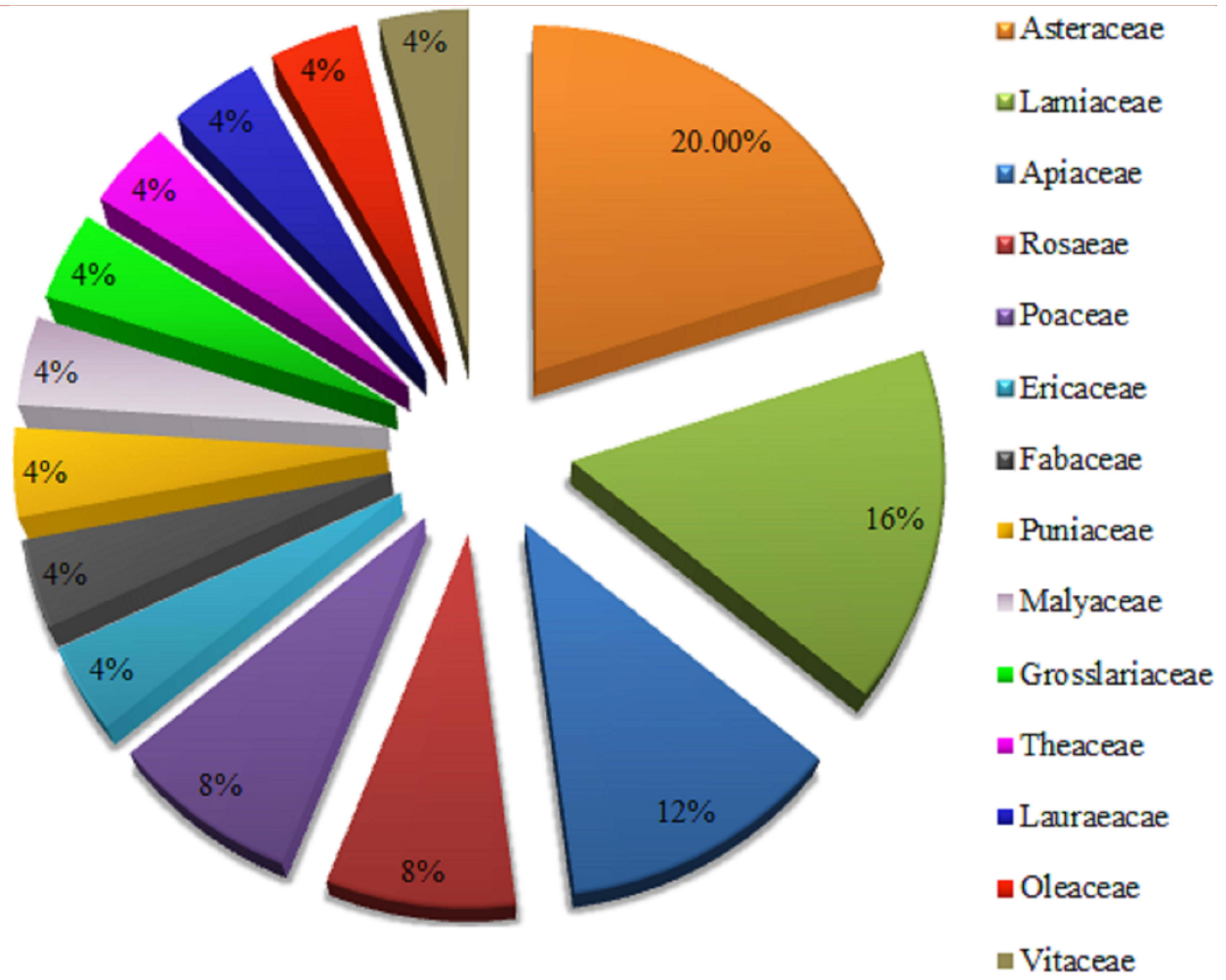

Figure 3 Percentage of botanical families having potential towards cardiovascular diseases.

a sufficient concentration of secondary metabolites, especially phenols and flavonoids responsible for their pharmacological actions in peripheral vascular diseases and cardiac abnormalities. Statistical analysis showed that the Asteraceae family possess a significant (20\%) number of plants having superb potential towards cardiovascular diseases. While plants of Lamiaceae, Apiaceae, Rosaceae, and Poaceae families have a percentage of $16 \%$ in the current review, which shows an abundant amount of polyphenols having a vital role in treatment of heart diseases.

\section{Mechanisms of Action of Cardio-Therapeutic Polyphenols}

To understand the mechanistic approaches adopted by most of the bioactive natural agents, especially polyphenols, various research reports have been analyzed. The findings have been manifested that polyphenol may function in CVS risk reduction through the regulation of different molecular pathways (Figure 4).

\section{Safety of Polyphenols}

To get the best therapeutic efficacy and longer duration of action, pharmacokinetic profiles and safety evaluations of natural substances have gained wide importance in this modern world. Most investigations of polyphenols intended to evaluate protective impacts of polyphenols against different ailments and harmful medications; however, few researchers have focused on their "safety profile" as well. ${ }^{46}$ No intense harmfulness was seen by using grape seed proanthocyanidin extract orally with a dose of $2 \mathrm{~g}$ per kilogram of body weight in Wistar albino rats after induction of a punicalagin $(60 \mathrm{~g} / \mathrm{kg})$ diet to rats. ${ }^{47}$ Notwithstanding, a high concentration of quercetin $(2 \%$ or $4 \%$ ) in the diet of rats caused chronic nephropathy, while no impact on survival time was seen, even though high quercetin $(0.1 \%)$ levels in diet altogether decreased the life expectancy of mice. ${ }^{48}$ Some polyphenols may have cancer-causing or genotoxic impacts at higher dose. ${ }^{49}$ For instance, development of renal tumors and forestomach infections has been linked with usage of $2 \%$ dietary caffeic acid in animals. Direct extrapolation of this information demonstrates significant risk at normal dietary levels. ${ }^{50}$ Besides, catechol-estrogens are hypothesized to cause renal cancer by estradiol. Quercetin restrains O-methylation of catechol-estrogens and elevates the renal concentration of 2- and 4-hydroxyestradiol by 60 $80 \%$, which may enhance the redox effect of catechol- 
Table 2 Summary of Different Plants Derived Polyphenols Having a Cardioprotective Effect

\begin{tabular}{|c|c|c|c|c|}
\hline Sr. No & Plant Name & Family & Polyphenolic Compound & References \\
\hline 1 & $\begin{array}{l}\text { Cynara } \\
\text { scolymus }\end{array}$ & Asteraceae & Quercetin, Apigenin-7-glucoside, Verbascoside, & [90] \\
\hline 2 & $\begin{array}{l}\text { Gundelia } \\
\text { tournefortii }\end{array}$ & Asteraceae & Luteolin-7-O-glycone, Chlorogenic acid, Rutin, Apigenin-7-O-glucoside & [68] \\
\hline 3 & $\begin{array}{l}\text { Achillea } \\
\text { millefolium }\end{array}$ & Asteraceae & $\begin{array}{l}\text { Chlorogenic acid, Vicenin-2, Luteolin-3-,7-di-O-glucoside, Luteolin-7-O-glucoside, } \\
\text { Rutin, Apigenin-7-O-glucoside, Luteolin, Apigenin }\end{array}$ & [18] \\
\hline 4 & $\begin{array}{l}\text { Carthamus } \\
\text { tinctorius }\end{array}$ & Asteraceae & $\begin{array}{l}\text { Catechin, Cyanidin, Delphinidin, Ellagic acid, Gallic acid, isoquercetin, Ursolic acid, } \\
\text { oleanolic acid, }\end{array}$ & [6] \\
\hline 5 & $\begin{array}{l}\text { Cichorium } \\
\text { intybus }\end{array}$ & Asteraceae & Caffeic acid, Quercetin, Kaempferol, Apigenin & [116] \\
\hline 6 & $\begin{array}{l}\text { Thymus } \\
\text { vulgaris }\end{array}$ & Lamiaceae & $\begin{array}{l}\text { Cryptochlorogenic acid, Homovanillic acid, Kaempferol, Ferulic acid, Gallic acid, } \\
\text { Vanillic acid, Naringin-c-hexoside, Hesperidin, Hesperetin }\end{array}$ & [97] \\
\hline 7 & $\begin{array}{l}\text { Salvia } \\
\text { miltiorrhiza }\end{array}$ & Lamiaceae & $\begin{array}{l}\text { Benzophenone, Iriflophenone-2-O- } \alpha \text {-L-rhamnopyranoside, Rosmarinic acid, } \\
\text { Rosmarinic acid methyl ester, salvianolic acid A methyl ester, salvianolic acid A ethyl } \\
\text { ester, }\end{array}$ & \\
\hline 8 & $\begin{array}{l}\text { Rosmarinus } \\
\text { officinalis }\end{array}$ & Lamiaceae & $\begin{array}{l}\text { Caffeic acid, Protocatechuic acid, Coumaric acid-O-hexoside, Cryptochlorogenic acid, } \\
\text { Rosmarinic acid-O-hexoside, Ferulic acid, Gallic acid, Vanillic acid, Naringin- } \\
\text { c-hexoside, Hesperidin, Hesperetin }\end{array}$ & [59] \\
\hline 9 & $\begin{array}{l}\text { Melissa } \\
\text { officinalis }\end{array}$ & Lamiaceae & Cinnamic acid, Caffeic acid, Rosmarinic acid, Protocatechuic acid & [22] \\
\hline 10 & $\begin{array}{l}\text { Cuminum } \\
\text { cyminum }\end{array}$ & Apiaceae & Caffeic acid, chebulagic acid, chebulinic acid & \\
\hline II & $\begin{array}{l}\text { Pimpinella } \\
\text { anisum }\end{array}$ & Apiaceae & $\begin{array}{l}\text { Catechin, Caffeic acid, Ferulic acid, Syringic acid, Cinnamic acid, Quercetin, Vanillic } \\
\text { acid, Chlorogenic acid, Luteolin, Apigenin }\end{array}$ & \\
\hline 12 & $\begin{array}{l}\text { Coriandrum } \\
\text { sativum }\end{array}$ & Apiaceae & Vanillic acid, Ferulic acid, Kaempferol, Quercetin, Acacetin & [38] \\
\hline 13 & $\begin{array}{l}\text { Cydonia } \\
\text { oblonga }\end{array}$ & Rosaceae & Phloretin, Neochlorogenic acid, Feruloylquinic acid, Quercetin, p-coumaric acid & [42] \\
\hline 14 & Rubus idaeus & Rosaceae & Ellagic acid, catechin, pelargonidin-3-rutinoside, cyanidin diglucoside & [22] \\
\hline 15 & $\begin{array}{l}\text { Eleusine } \\
\text { coracana }\end{array}$ & Poaceae & Naringin, kaempferol, Luteolin, apigenin, caffeic acid, ferulic acid, Syringic acid & [28] \\
\hline 16 & Secale cereale & Poaceae & Vanillic acid, $p$-coumaric acid, $t$-ferulic acid, Vanillin, sinapic acid, caffeic acid & [67] \\
\hline 17 & $\begin{array}{l}\text { Vaccinium } \\
\text { cyanococcus }\end{array}$ & Ericaceae & $\begin{array}{l}\text { Anthocyanins, } \\
\text { Chlorogenic acid, Hydroxycinnamic esters, Proanthocyanidins, Peonidin, Malvidin, } \\
\text { Delphinidin, Ellagic acid, Gallic acid }\end{array}$ & [58] \\
\hline 18 & $\begin{array}{l}\text { Phaseolus } \\
\text { vulgaris }\end{array}$ & Fabaceae & Flavanones, Flavonols, Flavones, Anthocyanins, coumestans, pterocarpans & [40] \\
\hline 19 & $\begin{array}{l}\text { Punica } \\
\text { granatum }\end{array}$ & Punicaceae & $\begin{array}{l}\text { Catechin, Cyanidin, Delphinidin, Ellagic acid, Gallic acid, isoquercetin, Ursolic acid, } \\
\text { oleanolic acid }\end{array}$ & [102] \\
\hline
\end{tabular}


Table 2 (Continued).

\begin{tabular}{|c|c|c|c|c|}
\hline Sr. No & Plant Name & Family & Polyphenolic Compound & References \\
\hline 20 & $\begin{array}{l}\text { Theobroma } \\
\text { cocoa }\end{array}$ & Malvaceae & $\begin{array}{l}\text { Catechin, Anthocyanins, Epicatechin, Catechin, Proanthocyanidins, cyanidin-3- } \alpha \text { - } \\
\text { L-arabinoside, Gallocatechin }\end{array}$ & [78] \\
\hline 21 & Ribes nigrum & Grossulariaceae & $\begin{array}{l}\text { Quercetin, p-coumaric acid, p-hydroxybenzoic acid, Gallic acid, Syringic acid, } \\
\text { Chlorogenic acid, Kaempferol, Caffeic acid derivatives, Myricetin-3-O-rutinoside }\end{array}$ & [48] \\
\hline 22 & $\begin{array}{l}\text { Camellia } \\
\text { sinensis }\end{array}$ & Theaceae & $\begin{array}{l}\text { Quercetin, Quinic acid, Caffeoyl glucose, Feruloylquinic acid, Catechin, Quercetin- } \\
\text { 3-O-rutinoside }\end{array}$ & [1] \\
\hline 23 & $\begin{array}{l}\text { Cinnamomum } \\
\text { zeylanicum }\end{array}$ & Lauraceae & Rutin, Catechin, Quercetin, Isorhamnetin, Kaempferol & [57] \\
\hline 24 & $\begin{array}{l}\text { Olea europaea } \\
\qquad \text { L. }\end{array}$ & Oleaceae & $\begin{array}{l}\text { Quercetin-3-O-rutinoside, Luteolin-7-O-glucoside, Luteolin-4'-O-glucoside, Apigenin- } \\
\text { 7-O-glucoside }\end{array}$ & [90] \\
\hline 25 & Vitis vinifera & Vitaceae & $\begin{array}{l}\text { Resveratrol, Epigallocatechin-3-gallate, Quercetin, Anthocyanins, Procyanidins, } \\
\text { Catechin, Epigallocatechin, p-coumaric acid, Ferulic acid }\end{array}$ & [2] \\
\hline
\end{tabular}

estrogens and estradiol-induced tumorigenesis. ${ }^{51}$ The in vitro genotoxic effects may be attributed to consumption of high doses on which polyphenols become "peroxidant". Moreover, various ex vivo experiments have been shown the production of glutathionyl quercetin adducts in tyrosinase-rich B16F-10 melanoma cells and in a myeloperoxidase-rich human HL-60 cell line, which provides significant evidence to the pro-oxidative digestion of quercetin inside the cell. ${ }^{52}$ This additionally

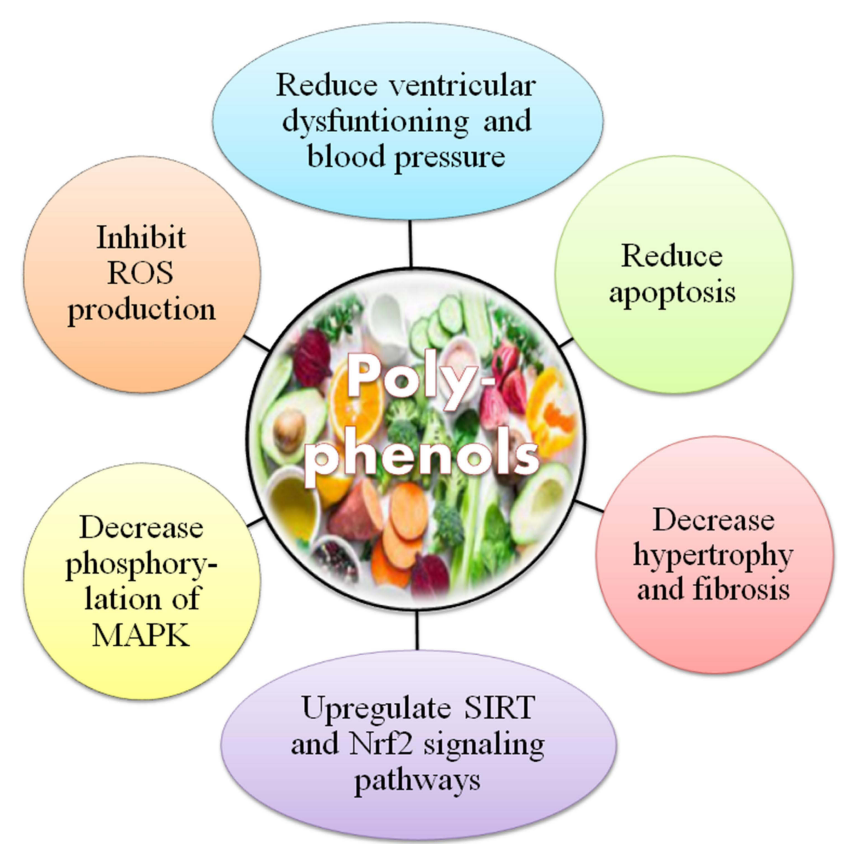

Figure 4 Possible mechanisms of polyphenols in the prevention of cardiovascular diseases.

Note: Data from Gormaz et al. ${ }^{119}$ recommends that tissues having excessive oxidative chemicals might be especially powerless against the prooxidant damage of quercetin. Lastly, green tea catechins ( $1 \%$ or $0.1 \%$ ) have been found to improve tumor advancement in the colon of F344 male rats and, although quercetin may diminish malignant cell growth at higher concentrations, it has been found to restore cell multiplication at low concentrations $(1-5 \mu \mathrm{mol} / \mathrm{L}) .^{53}$

Likewise, consumption of polyphenols may also have "anti-nutritional impacts". For instance, hindrance of nonheme iron absorption owing to concurrent tea utilization is notable as the intense usage of polyphenols may enhance the risk of iron exhaustion in heme-deficient individuals. ${ }^{54}$ Major sources of dietary polyphenols, like espresso, tea, and wine, which are routinely used, do not contain vitamin C, which typically enhances non-heme iron absorption. ${ }^{55}$ Moreover, proanthocyanidins and ellagitannins have been considered anti-nutritional compounds, especially in animal's diet as they can interact with proteins and deactivate series of enzymes. They influenced the development and digestion of rats when added to their routine food in a higher concentration $(10 \mathrm{~g} / \mathrm{kg}$ diet $)$, however not at a lower dose. ${ }^{56}$ Finally, drug bioavailability and pharmacokinetic profile may also influence by polyphenols, for instance, bioavailability of benzodiazepines and terfenadine is enhanced when administered in grapefruit juice (rich in naringenin) just due to the hindrance of CYP3A4 microsomal isoenzyme. ${ }^{57}$ These impacts, which might be inferable to some extent to "psoralens and naringenin', are clinically significant in the case of cyclosporine, a drug 


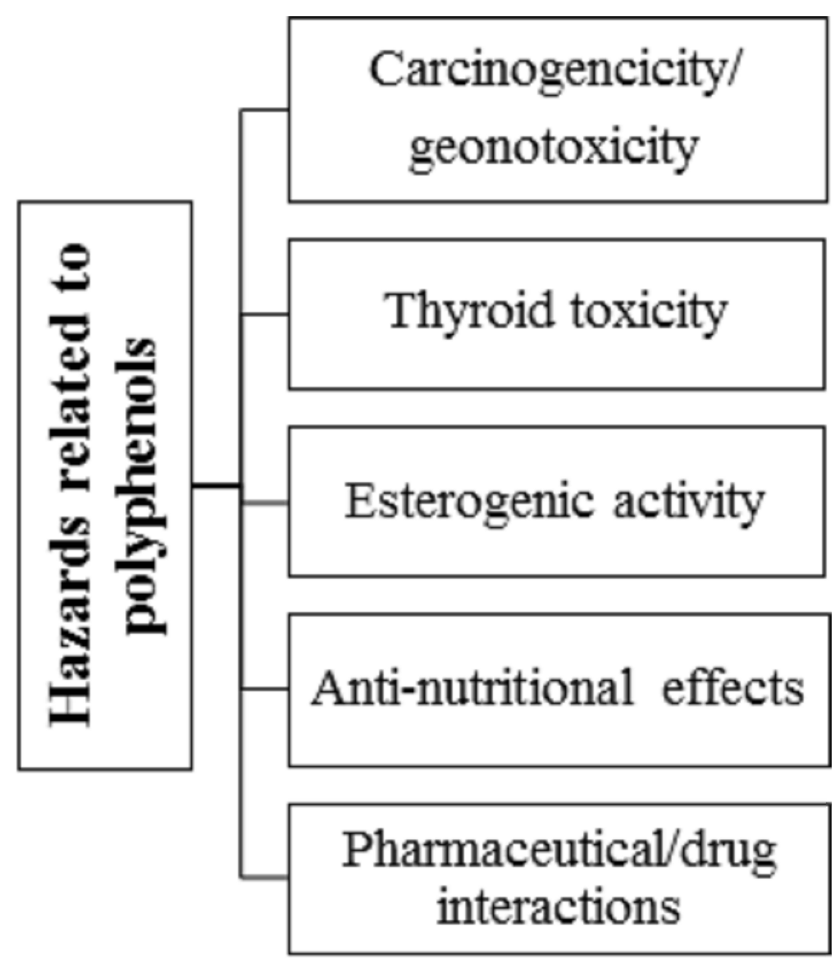

Figure 5 Hazards related to polyphenols. Note: Data from Cory et al. ${ }^{120}$

having a low therapeutic index. ${ }^{43}$ Different studies have exhibited toxic and mutagenic effects of polyphenols on higher doses, resultanting in mortality (Figure 5).

\section{Toxicity Studies of Polyphenols}

Natural compounds (polyphenols) are found to be safe even at higher doses as compared to synthetic and semisynthetic drugs. However, before initiating the clinical trials there is a dire need to evaluate the safety and efficacy of phenolic compounds through series of in vivo experiments. Certain phenolic compounds possess the capability to transform normal cells through tumorigenesis therefore, examination of toxicity and safety is a necessary measure, action into tumor-inducing agents. Tables 3-6 represent a summary of various polyphenolic compounds in terms of lethal dose and their detrimental impacts which have been studied until now in several experimental (in vivo and in vitro) studies.

\section{Polyphenols Effective in Cardiovascular Diseases (CVDs) Quercetin}

Quercetin is a polyphenol compound obtained mostly from different natural sources including fruits, vegetables, nuts, chocolate, coffee, spices, herbs, virgin olive oil, cocoa, black and green teas. Different studies have been generally revealed cardioprotective and cardio-therapeutic effect of quercetin $(\mathrm{Qu})$ flavonoids, particularly in treatment of atherosclerosis. ${ }^{58}$ Numerous biological mechanisms of quercetin have been discovered, for example, repressing arrangement of reactive oxygen species by obstructing nicotinamide-adenine dinucleotide phosphate (NADPH) oxidase, forestalling the development of atherosclerotic plaques by upregulating nitric oxide synthase enzyme and hampering plaques in endothelium by downregulating levels of metalloproteinase-1 (MMP-1). ${ }^{59,60}$ Bhaskar et al $^{61}$ reported the dose-dependent effect of quercetin on inflammation-induced hypercholesterolemia. The outcomes revealed quercetin an excellent scavenger towards reactive nitrogen and oxygen species and exerted an inhibitory effect on inflammatory enzymes such as 5-LOX, COX, NOS, and MPOs in mononuclear cells of animals.

Various in vitro studies have demonstrated the antiinflammatory potential of quercetin in cultured human cells (HuH7 hepatoma cells) with two humanized models of cardiovascular diseases in terms of inflammatory infections. Results showed the inhibitory effect of quercetin on inflammatory cardiovascular risk factors, eg, human CRP and fibrinogen, thus attenuating atherosclerosis. ${ }^{62}$ Furthermore, a recent study conducted by Mengjuan et al, 2020 exhibited that quercetin significantly suppressed endothelial dysfunctioning and atherosclerotic plaque by attenuating the expression of $\mathrm{p} 47 \mathrm{phox}$ and NADPH related oxidative damage attributed vital contribution of flavonoids in vascular diseases. ${ }^{63}$ However, a double-blind randomized clinical trial has demonstrated the profound effect of quercetin on systolic blood pressure, but nonsignificant activity was analyzed on diastolic blood pressure and inflammatory cytokines. Thus, in vitro biological effects of quercetin are not proven in human studies and need to be elucidated further on different doses to obtain the better outcomes. ${ }^{64}$ The cardioprotective impacts of quercetin have been reported in various models of exvivo cardiomyocyte injury. In a model of 4-hydroxynonenal-induced toxicity in $\mathrm{H} 9 \mathrm{c} 2$ heart cell line quercetin pretreatment $(0.1-10 \mu \mathrm{M}$ for 24 hours) diminished production of reactive oxygen species, p-SAPK/JNK levels, p-Hsp27 levels, and improved cell viability by ameliorating cardiomyocyte damage. ${ }^{65}$

The present review also focused on the safe use of quercetin signal dietary compound for critical health aspects. In 1999, the International Agency for Research 
Table 3 Safety Profile and Related Effects of Plants-Sourced Polyphenols

\begin{tabular}{|c|c|c|c|}
\hline $\begin{array}{l}\text { Polyphenolic } \\
\text { Compounds }\end{array}$ & Dose & Pharmacological Effects & References \\
\hline Gallic acid & $\begin{array}{l}5000 \mathrm{mg} / \mathrm{kg} \text { via oral route in an acute toxicity } \\
\text { study }\end{array}$ & Non-toxic & [8] \\
\hline Clovinol & $1,000 \mathrm{mg} / \mathrm{kg}$ b.w in subchronic toxicity study & Non-toxic & {$[115]$} \\
\hline Curcumin & $2,000-5,000 \mathrm{mg} / \mathrm{kg}$ & No adverse effects & [75] \\
\hline Rutin & Up to $5,000 \mathrm{mg} / \mathrm{kg}$ & Non-toxic & {$[106]$} \\
\hline Naringin & $\begin{array}{l}\text { I,250 } \mathrm{mg} / \mathrm{kg} \text { for period of } 6 \text { months (chronic } \\
\text { toxicological studies) }\end{array}$ & $\begin{array}{l}\text { Hair loss, decrease in body weight and food } \\
\text { consumption }\end{array}$ & [63] \\
\hline Myricitrin & 200,500 , and $I, 000 \mathrm{mg} / \mathrm{kg}$ in rats & No toxic effects & \\
\hline \multirow[t]{3}{*}{ Resveratrol } & A higher dose of $\mathrm{I} \mathrm{mg/kg}$ & Hypercholesterolemia-related atherosclerosis & [119] \\
\hline & 1,000 and $3,000 \mathrm{mg} / \mathrm{kg}$ & $\begin{array}{l}\text { Renal toxicity and nephropathy, reduction in weight of } \\
\text { lungs and heart }\end{array}$ & [78] \\
\hline & Lower dose $300 \mu \mathrm{g} / \mathrm{mL}$ & Non-toxic, good antioxidant & [8I] \\
\hline \multirow[t]{2}{*}{ Quercetin } & $2,4,6 \mathrm{~g} / \mathrm{kg}$ & No acute toxic effects & [3] \\
\hline & $8 \mathrm{~g} / \mathrm{kg}$ & $\begin{array}{l}\text { Neurotoxicity along with disruption of BBB and cause } \\
\text { jerks as well as writhes }\end{array}$ & [3] \\
\hline $\begin{array}{l}\text { Epigallocatechin } \\
\text { gallate }\end{array}$ & $50 \mu \mathrm{M}$ & Neurotoxicity along with disruption of BBB & [102] \\
\hline $\begin{array}{l}\text { Cyanidin- } \\
\text { 3-glucoside }\end{array}$ & $50 \mu \mathrm{M}$ & Neurotoxicity along with disruption of BBB & [84] \\
\hline \multirow[t]{2}{*}{ Benzoic acid } & $\begin{array}{l}800 \mathrm{mg} / \mathrm{kg} \text { body weight orally } \\
\text { and } 12 \mathrm{mg} / \mathrm{L} \text { aerosol/dust inhalation }\end{array}$ & Low toxicity level & [14] \\
\hline & Higher dose $>800 \mathrm{mg} / \mathrm{kg}$ & $\begin{array}{l}\text { Weight gain, lesions in kidneys, lungs, skeletal muscles, } \\
\text { stomach }\end{array}$ & {$[50]$} \\
\hline Kaempferol & $8 \mathrm{~g} / \mathrm{kg}$ & No acute toxic effects & [3] \\
\hline
\end{tabular}

on Cancer (IARC) inspected the expected cancer-causing hazard of quercetin to people and, in light of information accessible around then, arrived at the general resolution that "quercetin is not classifiable regarding its cancercausing nature to humans". 66 Various human clinical studies examined quercetin aglycone as a solitary compound or in a mix with high measures of nutrient $\mathrm{C}$ with or without a low dose of niacin/nicotinamide. Nonetheless, it was perceived, that the pre-owned dosages of nutrient $\mathrm{C}$ and niacin/nicotinamide might be too naturally dynamic and may affect the bioavailability of quercetin. ${ }^{67}$ Furthermore, other investigations involving quercetin aglycone in blend with at least one other presumably organically dynamic substance such as bromelain, curcumin, tea-catechin, and cinnamon bark extracts were also explored. These investigations were considered of minor significance concerning the safety profile of quercetin aglycone, because of open enquiries on the relevance of these studies results to organization of quercetin as a "single ingredient". Concerning utilization of quercetin in blend with nutrient $\mathrm{C}$, there are open enquiries regarding whether nutrient $\mathrm{C}$ may mitigate conceivable supportive of oxidative impacts of quercetin. ${ }^{68}$ Fundamentally, in vitro as well as some in vivo scientific studies have shown that even though quercetin showed antioxidative impacts intracellularly and quercetin itself was changed into oxidation products, o-semiquinone and o-quinone, which may respond with thiols and cause loss of protein function and cytotoxic effects. The pro-oxidative impacts of quercetin might be reliant upon the quercetin dose, 
Table 4 Comparison of Different Doses of Quercetin and Its Derivatives as a Cardioprotective Agent

\begin{tabular}{|c|c|c|c|c|}
\hline $\begin{array}{l}\text { Compound } \\
\text { Name }\end{array}$ & $\begin{array}{l}\text { Experimental Model } \\
\text { and Dose }\end{array}$ & Mechanism & Pharmacological Effect & References \\
\hline \multirow[t]{2}{*}{ Quercetin } & $\begin{array}{l}\text { Isoproterenol induced myocardial } \\
\text { infarction in rats }(20 \mathrm{mg} / \mathrm{kg})\end{array}$ & $\begin{array}{l}\text { Decrease reactive oxygen } \\
\text { species and levels of calpain }\end{array}$ & $\begin{array}{l}\text { Decrease inflammation and } \\
\text { oxidative stress }\end{array}$ & [56] \\
\hline & $\begin{array}{l}\text { Diabetic cardiomyopathy in rats }(10- \\
50 \mathrm{mg} / \mathrm{kg})\end{array}$ & $\begin{array}{l}\text { Decrease troponin levels, } \\
\text { low-density lipoproteins, } \\
\text { caspases } 3 \text { and } 9\end{array}$ & $\begin{array}{l}\text { Decrease cardiac damage, } \\
\text { inflammation, apoptosis and increase } \\
\text { cell viability }\end{array}$ & [46] \\
\hline Troxerutin & $\begin{array}{l}\text { In vivo rat model by inducing ischemia- } \\
\text { reperfusion }(150 \mathrm{mg} / \mathrm{kg})\end{array}$ & $\begin{array}{l}\text { Decrease levels of IL-Ib, } \\
\text { ICAM-I and TNF-alpha }\end{array}$ & $\begin{array}{l}\text { Decrease infarct size, arrhythmia } \\
\text { and inflammation ultimately increase } \\
\text { cardiac function }\end{array}$ & [76] \\
\hline Iso-quercetin & $\begin{array}{l}\text { In vitro assay on } \mathrm{H} 9 \mathrm{c} 2 \text { cells by inducing } \\
\text { ischemia-reperfusion }(20-80 \mu \mathrm{M} / \mathrm{mL})\end{array}$ & $\begin{array}{l}\text { Decrease ROS generation and } \\
\text { cytochrome-c release }\end{array}$ & $\begin{array}{l}\text { Increase cell viability and } \\
\text { mitochondrial protection. Also, } \\
\text { decrease apoptosis }\end{array}$ & [18] \\
\hline Isorhamnetin & $\begin{array}{l}\text { In vitro assay on } \mathrm{H} 9 \mathrm{c} 2 \text { cells by inducing } \\
\text { ischemia-reperfusion }(10-40 \mu \mathrm{M} / \mathrm{mL})\end{array}$ & $\begin{array}{l}\text { Decrease caspases } 3 \text {, } \\
\text { cytochrome-c release and } \\
\text { reactive oxygen species }\end{array}$ & $\begin{array}{l}\text { Enhance mitochondrial protection } \\
\text { and decrease oxidative damage }\end{array}$ & [43] \\
\hline $\begin{array}{l}\text { Dihydro- } \\
\text { quercetin }\end{array}$ & $\begin{array}{l}\text { In vitro assay }(\mathrm{H} 9 \mathrm{c} 2 \text { cells) and in vivo rat } \\
\text { model by inducing ischemia-reperfusion } \\
(5-20 \mu \mathrm{M} / \mathrm{mL})\end{array}$ & $\begin{array}{l}\text { Decrease apoptosis and } \\
\text { oxidative stress }\end{array}$ & $\begin{array}{l}\text { Decrease ROS, ER stress and PI3K/ } \\
\text { Akt }\end{array}$ & [92] \\
\hline
\end{tabular}

Table 5 Comparison of Different Doses of Naringin and Its Derivatives in Cardiovascular Diseases

\begin{tabular}{|c|c|c|c|c|}
\hline $\begin{array}{l}\text { Compound } \\
\text { Name }\end{array}$ & $\begin{array}{c}\text { Experimental Model and } \\
\text { Dose }\end{array}$ & Mechanism & $\begin{array}{c}\text { Pharmacological } \\
\text { Effect }\end{array}$ & References \\
\hline \multirow[t]{4}{*}{ Naringin } & $\begin{array}{l}\text { High-fat diet-induced rat } \\
\text { model }(100 \mathrm{mg} / \mathrm{kg} \text { body } \\
\text { weight) }\end{array}$ & $\begin{array}{l}\text { Ameliorated functioning of endothelium by enhancing } \\
\text { bioavailability of NO (nitric oxide) Moreover, exert } \\
\text { therapeutic effects against prolonged inflammation by } \\
\text { decreasing levels of inflammatory mediators } \\
\text { intracellularly }\end{array}$ & $\begin{array}{l}\text { Decrease blood } \\
\text { pressure and treat } \\
\text { hypertension }\end{array}$ & [4] \\
\hline & $\begin{array}{l}\text { Stroke-prone hypertensive } \\
\text { Wistar rats }(200,500 \text {, and } \\
1,000 \mathrm{mg} / \mathrm{kg})\end{array}$ & $\begin{array}{l}\text { Ameliorated functioning of endothelium by enhancing } \\
\text { bioavailability of NO (nitric oxide) }\end{array}$ & $\begin{array}{l}\text { Decrease cardiac } \\
\text { damage and } \\
\text { hypertension }\end{array}$ & [97] \\
\hline & $\begin{array}{l}\text { Isoproterenol induced } \\
\text { myocardial infarction in rats } \\
(10,20 \text {, and } 40 \mathrm{mg} / \mathrm{kg})\end{array}$ & Decreased lipid peroxidation and levels of ROS & $\begin{array}{l}\text { Cardioprotective } \\
\text { agent }\end{array}$ & [3] \\
\hline & $\begin{array}{l}\text { Doxorubicin-induced } \\
\text { cardiotoxicity (10 mg/kg } \\
\text { body weight) }\end{array}$ & $\begin{array}{l}\text { The reduced serum concentration of AST, LDH, and } \\
\text { CK-MB }\end{array}$ & $\begin{array}{l}\text { Protected against } \\
\text { cardiotoxicity }\end{array}$ & [61] \\
\hline Naringenin & $\begin{array}{l}\text { In vitro assay on } \mathrm{H} 9 \mathrm{c} 2 \\
\text { cardiomyocyte cells }\end{array}$ & $\begin{array}{l}\text { Naringenin produced an inhibitory effect against } \\
\text { daunorubicin apoptosis of } \mathrm{H} 9 \mathrm{c} 2 \text { cardiomyocyte cells }\end{array}$ & $\begin{array}{l}\text { Decreased } \\
\text { inflammation } \\
\text { ultimately increase } \\
\text { cardiac function }\end{array}$ & [75] \\
\hline
\end{tabular}

exposure time, and cell-mediated redox reactions. ${ }^{69}$ Wee et $\mathrm{al}^{70}$ explored that oral admission of quercetin in people is endured and just an extremely low frequency of unwanted effects has been analysed to date. After administration of a moderately low quercetin portion of $150 \mathrm{mg}$ quercetin each day for about a month and a half, certain 
Table 6 Plants Derived Natural Polyphenols in Pre-Clinical and Clinical Trials Against Cardiovascular Diseases

\begin{tabular}{|c|c|c|c|c|}
\hline $\begin{array}{l}\text { Compound } \\
\text { Name }\end{array}$ & Experimental Model and Dose & Mechanism & Pharmacological Effect & References \\
\hline \multirow[t]{3}{*}{ Resveratrol } & $\begin{array}{l}\text { Randomized study on } 34 \text { patients with } \\
\text { metabolic syndrome ( } 100 \mathrm{mg} \text { resveratrol with } \\
\text { a combination of quercetin and vitamin D3 and } \\
\text { rice bran) }\end{array}$ & $\begin{array}{l}\text { Increased in blood flow- } \\
\text { mediated dilation and improved } \\
\text { endothelial dysfunction }\end{array}$ & $\begin{array}{l}\text { Anti-inflammatory, } \\
\text { Antihypertensive, Lipid- } \\
\text { lowering agent }\end{array}$ & [33] \\
\hline & $\begin{array}{l}\text { Placebo controlled double-blind randomized } \\
\text { study on hypertensive patients }(n=24) \text { with } \\
\text { metabolic syndrome ( } 300 \mathrm{mg} \text { resveratrol OD) }\end{array}$ & $\begin{array}{l}\text { Improved function of } \\
\text { endothelium function and no } \\
\text { effects on blood pressure and } \\
\text { augmentation index }\end{array}$ & $\begin{array}{l}\text { Anti-inflammatory, } \\
\text { Hypercholesterolemia agent } \\
\text { and lipid-lowering drug, } \\
\text { Cardioprotective }\end{array}$ & [97] \\
\hline & $\begin{array}{l}\text { Triple blind randomized placebo-controlled } \\
\text { study on } 75 \text { stable coronary artery disease } \\
\text { patients with metabolic syndrome ( } 370 \mathrm{mg} \\
\text { resveratrol capsule with } 350 \mathrm{mg} \\
\text { Stilvid OD) }\end{array}$ & $\begin{array}{l}\text { Decreased lipid peroxidation } \\
\text { and levels of ROS }\end{array}$ & Cardiovascular effects & [95] \\
\hline Curcumin & $\begin{array}{l}\text { Randomized controlled trials double-blind trial } \\
\text { ( } 70 \mathrm{mg} / \text { day curcuminoids) }\end{array}$ & $\begin{array}{l}\text { Increased cell viability and } \\
\text { mitochondrial protection. Also, } \\
\text { decrease apoptosis }\end{array}$ & $\begin{array}{l}\text { Anti-inflammatory, } \\
\text { Hypercholesterolemia, } \\
\text { antioxidant }\end{array}$ & [8] \\
\hline $\begin{array}{l}\text { Catechin and } \\
\text { Epicatechins }\end{array}$ & $\begin{array}{l}\text { A perspective cohort study on women } \\
(34,492) \text { for } 13 \text { years. Catechin }\end{array}$ & $\begin{array}{l}\text { Decreased lipid peroxidation } \\
\text { and levels of ROS }\end{array}$ & $\begin{array}{l}\text { Anti-inflammatory, } \\
\text { antioxidant, } \\
\text { Cardioprotective effects, } \\
\text { impedes coronary artery } \\
\text { disease }\end{array}$ & [8] \\
\hline
\end{tabular}

boundaries of liver and kidney capacity, hematology, and serum electrolytes were estimated in obese people. All findings showed normal ranges of respective laboratory parameters as compared to reference values. Another study was performed on $500 \mathrm{mg}$ quercetin with $500 \mathrm{mg}$ nutrient $\mathrm{C}$ and $20 \mathrm{mg}$ nicotinamide each day or $1,000 \mathrm{mg}$ quercetin with $1,000 \mathrm{mg}$ nutrient $\mathrm{C}$ and $40 \mathrm{mg}$ nicotinamide each day for 12 weeks. Each group included around 330 people, of which $37 \%$ had a history of at least one constant illness. Outcomes exhibited no significant harmful effects on patient's health. ${ }^{71}$ Regarding the utilization of quercetin as a solitary compound, logical data for safety assessment of quercetin from human clinical studies is restricted because of lack of authentic safety profile, particularly thinking about the long-term treatment $(>12$ weeks) with high-concentration supplemental quercetin applications $\left(1,000 \mathrm{mg} \mathrm{d}^{-1}\right)^{72}$ (Table 4).

\section{Naringin}

Naringin is a flavonoid compound that belongs to subclass flavones and is extensively distributed in "citrus fruits" such as bergamot and tomatoes. Naringin is a remarkable polyphenolic compound having wide organic effects on human wellbeing. This secondary metabolite incorporates a reduction in lipid peroxidation biomarkers and protein carboxylation, advances glucose digestion, builds a cancer prevention agent, decreases levels of ROS, and applies hostility to atherogenic and calming impacts. ${ }^{73}$ It has likewise been an extraordinary capacity to balance macromolecular pathways identified with unsaturated fats digestion, which favors unsaturated fats oxidation, hinders lipid accumulation in the liver, and this manner prevents fatty liver other than effectively disabling plasma lipids and lipoproteins collection. ${ }^{74}$ Moreover, naringenin (derivative of naringin) potentiates intracellular reactions to low insulin dosages by sharpening hepatocytes to insulin, other than having the option to cross the blood-brain barrier (BBB) and to exert different neuronal impacts, through its capacity to cooperate with protein kinase C pathways. $^{75}$ Anti-malignant, anti-proliferative, and anticarcinogenic impacts have additionally been attributed to this metabolite ${ }^{76}$ due to its excellent capacity to fix DNA. Additionally, antiviral impacts have accounted for naringenin showing a significant inhibitory response 
against dengue infection, blocking intracellular replication of chikungunya infection, ${ }^{77}$ and hindering irresistible hepatitis $\mathrm{C}$ infection. However, this bioflavonoid is inadequately consumed by oral ingestion, with just $15 \%$ of ingested naringenin retained in the human gastrointestinal parcel, ${ }^{78}$ which has set off a few investigations on its bioavailability. A recent study has revealed that pretreatment with different doses $(10,20$, and $40 \mathrm{mg})$ of naringin decrease oHdG and poly ADP-ribose polymerase enzyme activity in the heart and liver of mice, which ultimately downregulates mitochondrial tri-carboxylic acid enzyme activity. In addition, naringin is a well-known cardioprotective agent due to its efficient capability against hyperglycemia associated ROS-activated MAPK signaling mediated pathway (Table 5).

\section{Resveratrol}

Resveratrol (3, 5, 4'-trihydroxy-trans-stilbene) is a polyphenolic stilbene obtained by different plants. Although people can acquire modest quantities of resveratrol in specific food varieties like peanuts, grapes, berries, and so on, a significant amount of dietary-sourced resveratrol has been consumed in multiple scientific works. ${ }^{79}$ A large number of clinical studies have been conducted to analyze the viability of resveratrol in treating patients with heart failure ${ }^{80}$ to measure impacts of resveratrol on variables identified with the pathogenesis of atherosclerosis and chronic artery disease by altering inflammatory, arachidonic acid metabolism, and endothelial functioning pathways. ${ }^{81}$ Most of the preclinical studies have shown the therapeutic efficacy of resveratrol in mice/rat pressure-over-burden incited HF models by improving diastolic pressure, cardiovascular remodeling, myocardial functioning, vascular blood flow and preventing heart fibrosis. ${ }^{82}$

\section{Curcumin}

Curcumin is a principal curcuminoid of "curcuma longa" which is traditionally applied to forestall different chronic pathological conditions. Several ongoing investigations have reported the extraordinary role of this phytochemical in regulation of "signaling pathways" such as cellular proliferation and differentiation, tolerance, and oxidative stress. One pre-clinical study was conducted by Li et al to explore the therapeutic potential of curcumin in male mice having aortic aneurysm induced by transient elastase perfusion of stomach aorta. Findings had shown a marked decrease in the expansion of aortic breath, improvement in elastin integrity, and lower levels of inflammatory mediators, eg, tumor necrosis factor-alpha (TNF- $\alpha$ ), nuclear factor kappa- $\beta(\mathrm{NF}-\kappa \beta)$, and activator protein-1 (AP-1), as with administration of curcumin $(100 \mathrm{mg} / \mathrm{kg} /$ day) for 14 days. Moreover, studies have been proven that curcumin adds to decreasing the frequency of atherosclerosis. The first study had been conducted in ApoE -/-/LDLR-/- mice to evaluate restorative impacts of curcumin $(0.3 \mathrm{mg} / \mathrm{d} / \mathrm{mice})$ on an atherosclerosis. Results have shown that curcumin treatment exerted a significant effect against atherosclerosis progression, in spite of producing no extraordinary therapeutic effect on body weight and lipid profile of mice. ${ }^{83}$ Moreover, another study also supported the results of the previous one by exhibiting remarkable changes in gene expression of leukocytes attachments and endothelial cells movement in aortic tissues of ApoE induced mice treated with curcumin $(0.2 \%$ $\mathrm{w} / \mathrm{w}$ in diet, 4 months). ${ }^{84}$ These effects represent strong pharmacological activity of curcumin against atherosclerosis through activation of inhibitor of $N F-\kappa B(\mathrm{I} \kappa \mathrm{B})$ and decreasing the expression of inflammatory mediators (eg,

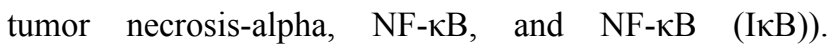
Furthermore, significant downregulation of toll-like receptor 4 (TLR4) activation has also been analyzed with the treatment of curcumin $(0.1 \% \mathrm{w} / \mathrm{w}$ in diet, 16 weeks $)$ in ApoE induced mice. ${ }^{85}$

In cardiac contractility and myocytes functioning calcium signaling plays a crucial role, and cardiovascular breakdown is constantly joined by deregulated calcium concentration. Curcumin had the option to smother cardiovascular hypertrophy and cardiovascular breakdown by interfering in pathways regulated via calcium. For example, change in location of sodium-calcium exchangers, maintenance of calcium concentration in sarcoplasmic reticulum and also upregulate Ca-ATPase expression intracellularly by hampering calcium-calmodulin protein kinase-II and calcineurin factor of lymphocytes (NFAT). ${ }^{86}$ Cardiac fibrosis is a "neurotic trademark" for the change to cardiovascular breakdown advanced from cardiac enlargement as well as accumulation of extracellular proteins (collagen type-1) in inter-myocardium. Liu et al ${ }^{87}$ demonstrated the inhibitory effect of curcumin $(200 \mathrm{mg} / \mathrm{kg} / \mathrm{day}$ for 3 days $)$ on collagen deposition in isoproterenol (Iso)treated rats. In addition, findings exhibited that curcumin repressed the mammalian rapamycin (mTOR)/autophagy signaling pathway, thus efficiently controlled cardiac hypertrophy and fibrosis occurred due to isoproterenol.

To date, several studies have been conducted to investigate the cardiotoxic and cardioprotective effects of 
curcumin in "doxorubicin" induced cardiomyopathy or cardiomyocytes injury in rats. Doxorubicin elevated levels of serum creatinine kinase and lactate dehydrogenase joined by suppressed expression on glutathione peroxidase and catalase antioxidant enzymes antioxidants intracellularly. However, outcomes showed suppressive action of curcumin $(200 \mathrm{mg} / \mathrm{kg} /$ day) for 4 weeks duration on cardiotoxicity profile of animals, thus it may be used as a cardioprotective agent to forestall heart injury in doxorubicin-treated Wistar albino rats. ${ }^{88,89}$

\section{Salvianolic Acid}

An in vivo research study had been conducted to assess the therapeutic action of salvianolic acid on Guinea pig heart exposed with hypoxia associated myocardial injury induced with nitro oxide synthase expression. ${ }^{90}$ Furthermore, in vitro studies have manifested the antiatherosclerosis effect of salvianolic acid on H-mon DC cells/tissues by suppressing activation of PPAR- $\gamma$ nuclear translocation, regulation of toll-like receptors, and expression of CD40, CD86, interleukins, and tumor necrosis factor-alpha. ${ }^{91}$ An in vivo study demonstrated that pretreatment with salvianolic acid for continuous 8 days exerted excellent potential towards isoproterenol-induced myocardial infarction and myocardial injury by elevating levels of lactate dehydrogenase, creatinine kinase, and malondialdehyde. $^{92}$

\section{Catechins/Epigallocatechin}

Numerous epidemiological, pre-clinical, and clinical studies have formed a positive relationship between natural products "green tea' and cardiovascular health. Green tea possesses "catechin", a class of polyphenols having multiple pharmacological actions including antioxidant capacity, inhibition of lipid enzymes biosynthesis, downregulation of vascular inflammation, impeding effect on smooth muscles proliferation, and so on. The majority of scientific reports have shown a strong potential of catechins towards the mitigation of CVDs. ${ }^{93}$ Hayek et al found a 39\% reduction in aortic atherosclerotic arch lesions in 40 apolipoprotein $\mathrm{E}$ (ApoE) deficient mice that were administered with catechin-rich water ( $50 \mu \mathrm{g} /$ day $)$ for 6 weeks as compared to placebo. A 31\% decrease was observed in low-density lipoprotein levels and less susceptibility towards oxidation. ${ }^{94}$

Moreover, one study reported that feeding of atherogenic diet in ApoE-deficient mice and pre-treatment with $3.2 \mathrm{mg} /$ day of green tea extract containing $(584 \mathrm{mg} / \mathrm{g}(-)$ epigallocatechin-gallate, $117 \mathrm{mg} / \mathrm{g}(-)$ epigallocatechin, $66 \mathrm{mg} / \mathrm{g} \mathrm{(-)} \mathrm{epicatechin,} 16 \mathrm{mg} / \mathrm{g} \mathrm{(+)} \mathrm{gallocatechin} \mathrm{gallate,}$ and $5 \mathrm{mg} / \mathrm{g}(-)$ epicatechin gallate) over 2 weeks may exert significant attenuation in atherosclerosis aortic area than the placebo group. ${ }^{95}$ Reis et al $^{96}$ conducted a cohort study on 5,115 subjects over 20 years and reflected on the excellent efficacy of green tea against coronary artery disease just because of the rich content of polyphenolic compounds such as catechin and epicatechin. Various foods in a normal diet are high in flavan-3-ols, including tea, nuts, cocoa (chocolate), grapes (wine), and legumes, and their beneficial outcomes on cardio-metabolic disorders, eg, diabetes, and cardiovascular diseases hae been observed. Standard chocolate usage has additionally been related to a valuable impact on blood vessel solidness, which is associated with the improvement of systolic hypertension. ${ }^{97}$ Likewise, results of a forthcoming enormous, cancer nutrition cohort prevention study showthat consumption of polyphenolic compounds, especially flavan-3-ols, can decrease cardiovascular infection risk efficiently. ${ }^{98}$ Meta-analysis of cohort, case-control, and cross-sectional investigation revealed a 37\% lower risk of any cardiovascular illness, a $31 \%$ decrease in diabetes, and a $29 \%$ decline in risk of stroke in people who consumed rich content of cocoa and chocolate, nonetheless, no critical impact was seen on cardiovascular breakdown. $^{99}$ Meta-analysis of several observational investigations has likewise announced that flavan-3-ols rich food sources can decrease the frequency of cardiac stroke as well as myocardial infarction related hazards. ${ }^{100}$ Furthermore, a meta-analysis of randomized, controlled preliminaries detailed that cocoa flavan-3-ols from enhancements and dietary sources produce unassuming, however critical, upgrades in cardio-metabolic biomarkers (ie, lipid peroxidation, insulin insufficiency, and chronic inflammation or fibrosis). ${ }^{101}$

\section{Gallic Acid}

Gallic acid is a part of "esters of gallotannins" having a strong antioxidant capacity and free radical scavenging potential. Likewise, gallic acid also possesses antibacterial, antiviral, anti-inflammatory, antitumor, and apoptotic actions. ${ }^{102}$ Different studies have shown the protective effects of gallic acid towards doxorubicin-induced, isoproterenol-induced, indane-incited cardiotoxicity and secure diabetes-associated myocardial damage in Wistar rats. The extensive profile of pharmacological actions of gallic acid is attributed to a massive concentration of secondary 
metabolites (polyphenols) and their antioxidant activity in natural resources. ${ }^{103}$

\section{Iso-Flavone}

Several epidemiological investigations have demonstrated that the utilization of soy-containing food may forestall or hinder the advancement of cardiovascular sickness. In endothelial cells use of soy extract and a blend of soy isoflavones (genistein + daidzein) both repressed apoptosis, the main thrust in atherosclerosis advancement, when applied in a mix with oxidized LDL or homocysteine. ${ }^{104}$ Proteome investigation uncovered that consumption of genistein/daidzein mixture and soy extract reverted stressor-incited variations of protein expression. In addition, proteins isolated by proteome investigation revealed that soy isoflavones may build the mitigating response in blood mononuclear cells in this manner adding atherosclerosispreventive characteristics of a soy-rich extract. ${ }^{105}$

Isoflavones are a group of polyphenols that are due to their "estrogen-like action" which provide them antagonistic characteristics in Asian people, levels of plasma isoflavone are for the most part somewhere in the range of $0.05-5 \mu \mathrm{mol} / \mathrm{L}$, which addresses buyers of a lot of isoflavone-rich items like soy. Though a conventional Asian eating regimen of $20-120 \mathrm{mg}$ isoflavones/day is used, for western people the permissible limit for the eating regimen is assessed as $0.2-5 \mathrm{mg}$ /day. High admissions have been related to diminished ripeness in creatures and luteinizing chemical impacts among premenopausal ladies. Besides, concerns have been communicated regarding the sexual development of newborn children getting significant degrees of isoflavones in the soy-based baby equation. This is of specific significance for child young men, who ordinarily display luteinizing chemical emission at birth and 6 months old . It is consequently critical to take note of the advantageous impacts of isoflavones on the advancement of malignant growth through the restraint of specific proteins seen at levels that are generally a lot higher (some $>20$ times higher) than those noticed ordinarily in human plasma. At these levels, isoflavones may have antiandrogenic impacts, impact male and female ripeness and sexual advancement in utero and after birth, and prompt testicular atrophy. ${ }^{106}$

\section{Caffeic Acid}

Caffeic acid (CAA) is an important member of "hydroxycinnamic acid" with natural antioxidant and cardio- protective properties. Agunloye et $\mathrm{al}^{107}$ showed significant activity of caffeic acid (10 and $15 \mathrm{mg} / \mathrm{kg}$ ) towards heart rate and hypertensive condition through enhancing nitric oxide bioavailability, increased catalase activity, decreasing glutathione, and malondialdehyde content in rats. Moreover, synthetic derivatives of caffeic acid such as caffeic acid phenyl amide (CAPA) and caffeic acid ethanolamine (CAEA) possess cytoprotective action as compared to the parent compound. Studies have shown that CAA, CAEA, and CAPA depicted promising biological action against cardiovascular events due to their "vasorelaxant activity" on endothelial and vascular smooth muscle cells. ${ }^{108}$ In addition, caffeic acid has been shown to have "antioxidant, anti-inflammatory and cardioprotective effects" following regional myocardial ischemia/reperfusion injury ultimately re-perfused contractile function and reduces infarct size. ${ }^{109}$ One study has validated the pharmacological effect of CAA (dose of $15 \mathrm{mg} / \mathrm{kg}$ ) against cyclosporine-induced cardiotoxicity in rats by improving cardiac architecture and downregulating metalloproteinase-2 (MMP-2) expression. ${ }^{110}$

\section{Kaempferol}

Kaempferol is a yellow common natural "flavonoid" abundant in many plant-derived foods and traditional medicine. Its glycosides possess numerous pharmacological activities including antiradical capacity, antibacterial or antifungal activity, chemotherapeutics, neuroprotective, hypoglycemic, pain relieving, and anti-allergic. ${ }^{111}$ Furthermore, the anti-atherosclerotic effect of kaempferol was investigated in a cholesterol-induced atherosclerosis rabbit model centered on endothelium cells, thus worked through downregulation of TNF- $\alpha$ as well as by improving antioxidant ability. ${ }^{112}$ Another study has delineated the effect of Kaempferol (KF) on heart failure (HF) in diabetic rats. Findings have demonstrated the reduction in cardiac apoptosis with kaempferol treatment via regulation of $\mathrm{Nrf2}$ (nuclear factor kappa light chain enhancer of activated B-cells) and Akt/GSK signaling pathways which confirmed the cardioprotective effect of Kaempferol. ${ }^{113}$

\section{Clinical Trials on Polyphenols Against CVDs}

Data in Table 6 represented a summary of clinically studied medicinal plants which are safe and potent, hence can be used to treat cardiovascular diseases. Data showed a significant reduction in cardiac abnormalities with continuous consumption of plant-based polyphenols and their 
derivatives, suggesting them as suitable "cardioprotective agents" (Table 6). In addition to this, nutraceuticals derived from foods of vegetal and animal origin exert a beneficial role on health. Various observational and intervention studies presented a promising link between the intake of a polyphenols-rich diet and cardiac diseases. $^{114}$ Tresserra et $\mathrm{al}^{115}$ have conducted a multicentered, randomized clinical trial $(n=7,447)$ that involved the administration of polyphenol feed for 5-years. Findings showed a $37 \%$ relative reduction in death rate among heart disease patients and enhanced longevity. Likewise, a geriatric population ( $>65$ years) based cohort clinical trial suggested that long-term use of polyphenols increases life expectancy for old age cardiac patients. ${ }^{116}$ Among all polyphenols, stilbenes and lignans were found to be more effective, which reduced all-cause mortality. ${ }^{117}$

\section{Conclusion}

To summarize, polyphenols (PPs) are vital health-promoting components and can have in vivo cardioprotective activity, but the fundamental mechanisms that underpin their protective activity are much less clear. Polyphenols can regulate enzyme activities, modulate gene expression and intracellular signaling, thus possesses superb antioxidant, immunomodulatory, and anti-inflammatory properties responsible for their effectiveness in treatment of cardiovascular diseases. Therefore, the use of some polyphenols as adjuvant or novel treatment might provide a potential strategy to alleviate cardiac pathologies. Besides this, individual usage or rational combinations of different polyphenolic compounds is found to be effective and safe in lowering chronic events of cardiac pathologies and vascular abnormalities. Collectively, this review suggests that a polyphenols-rich diet and products may be a cornerstone for a healthy life by preventing development and progression of cardiovascular and related metabolic pathologies. However, inconsistent results have been observed in different trials, thus more accurate and long-term clinical studies are warranted to note the effect of polyphenols on cardiac problems and associated mortality rate.

\section{Future Perspectives}

There are several challenges to our current understanding of the consumption of plants-based polyphenols in cardiovascular hard-points therefore several translational, mechanistic studies, as well as short-term clinical studies with immediate cardiovascular markers (eg, proinflammatory adhesion markers of measures of endothelial function, plasma or urinary tyrosol), could be planned within the bigger trial. Undoubtedly, physiological efficacy or toxicity depends on the dosage and our review revealed that the number of polyphenols evaluated for their toxicity is very limited, thus there is a dire need to undertake further qualitative as well as quantitative studies on safety investigations of polyphenols.

\section{Acknowledgment}

This research was funded by the Deanship of Scientific Research at Princess Nourah bint Abdulrahman University through the Fast-Track Path of Research Funding Program.

\section{Disclosure}

The authors report no conflicts of interest for this work.

\section{References}

1. Lopez EO, Ballard BD, Jan A. Cardiovascular Disease. StatPearls; 2020.

2. Jafar TH, Qadri Z, Chaturvedi N. Coronary artery disease epidemic in Pakistan: more electrocardiographic evidence of ischaemia in women than in men. Heart. 2008;94(4):408-413. doi:10.1136/hrt.2007.120774

3. Biglu M-H, Ghavami M, Biglu S. Cardiovascular diseases in the mirror of science. J Cardiovasc Thor Res. 2016;8(4):158. doi:10.15171/jevtr.2016.32

4. Nazon E. An overview of cardiovascular disease and research. WR-467-RS; 2007.

5. Nichols M, Townsend N, Scarborough $P$, Rayner M. Cardiovascular disease in Europe 2014: epidemiological update. Eur Heart J. 2014;35:2950-2959. doi:10.1093/eurheartj/ehu299.

6. Yusuf S, Wood D, Ralston J, Reddy KS. The World Heart Federation's vision for worldwide cardiovascular disease prevention. Lancet. 2015;386(9991):399-402. doi:10.1016/S01406736(15)60265-3

7. Mensah GA, Roth GA, Fuster V. The Global Burden of Cardiovascular Diseases and Risk Factors: 2020 and Beyond. Washington, DC: American College of Cardiology Foundation; 2019.

8. Zubair F, Nawaz SK, Nawaz A, Nangyal H, Amjad N, Khan MS. Prevalence of cardiovascular diseases in Punjab, Pakistan: a cross-sectional study. J Public Health (Bangkok). 2018;26 (5):523-529. doi:10.1007/s10389-018-0898-4

9. Yusuf $\mathrm{S}$, Islam $\mathrm{S}$, Chow CK, et al. Use of secondary prevention drugs for cardiovascular disease in the community in high-income, middle-income, and low-income countries (the PURE Study): a prospective epidemiological survey. Lancet. 2011;378(9798):1231-1243. doi:10.1016/S0140-6736(11)6121 $5-4$

10. Mahmood SS, Levy D, Vasan RS, Wang TJ. The Framingham heart study and the epidemiology of cardiovascular disease: A historical perspective. Lancet. 2014;383(9921):999-1008. doi:10.1016/S0140-6736(13)61752-3

11. Rodriguez-Araujo G, Nakagami H. Pathophysiology of cardiovascular disease in diabetes mellitus. Cardiovasc Endocrinol Metabol. 2018;7(1):4. doi:10.1097/XCE.0000000000000141

12. Siti HN, Kamisah Y, Kamsiah J. The role of oxidative stress, antioxidants and vascular inflammation in cardiovascular disease (a review). Vascul Pharmacol. 2015;71:40-56. doi:10.1016/j. vph.2015.03.005 
13. Moris D, Spartalis M, Spartalis E, et al. The role of reactive oxygen species in the pathophysiology of cardiovascular diseases and the clinical significance of myocardial redox. Ann Transl Med. 2017;5:16.

14. Shayganni E, Bahmani M, Asgary S, Rafieian-Kopaei M. Inflammaging and cardiovascular disease: management by medicinal plants. Phytomedicine. 2016;23(11):1119-1126. doi:10.1016/j.phymed.2015.11.004

15. Petrie JR, Guzik TJ, Touyz RM. Diabetes, hypertension, and cardiovascular disease: clinical insights and vascular mechanisms. Can J Cardiol. 2018;34(5):575-584. doi:10.1016/j. cjca.2017.12.005

16. Kim JH, Shah P, Tantry US, Gurbel PA. Coagulation abnormalities in heart failure: pathophysiology and therapeutic implications. Curr Heart Fail Rep. 2016;13(6):319-328. doi:10.1007/s11897-016-0308-6

17. Denham NC, Pearman CM, Caldwell JL, et al. Calcium in the pathophysiology of atrial fibrillation and heart failure. Front Physiol. 2018;9:1380.

18. Scott J. Pathophysiology and biochemistry of cardiovascular disease. Curr Opin Genet Dev. 2004;14(3):271-279. doi:10.1016/j.gde.2004.04.012

19. Gisterå A, Hansson GK. The immunology of atherosclerosis. Nat Rev Nephrol. 2017;13(6):368. doi:10.1038/nrneph.2017.51

20. Kattoor AJ, Pothineni NVK, Palagiri D, Mehta JL. Oxidative stress in atherosclerosis. Curr Atheroscler Rep. 2017;19 (11):1-11. doi:10.1007/s11883-017-0678-6

21. Li L, Zhou X, Li N, Sun M, Lv J, Xu Z. Herbal drugs against cardiovascular disease: traditional medicine and modern development. Drug Discov Today. 2015;20(9):1074-1086. doi:10.1016/j.drudis.2015.04.009

22. Gunjan M, Naing TW, Saini RS, Ahmad A, Naidu JR, Kumar I. Marketing trends \& future prospects of herbal medicine in the treatment of various disease. World J Pharm Res. 2015;4 (9):132-155.

23. Khan A, Safdar M. Role of diet, nutrients, spices and natural products in diabetes mellitus. Pak J Nutri. 2003;2:1-12.

24. Haslam E. Natural polyphenols (vegetable tannins) as drugs: possible modes of action. J Nat Prod. 1996;59(2):205-215.

25. Sun J, Tan BK, Huang S-H, Whiteman M, Zhu Y-Z. Effects of natural products on ischemic heart diseases and cardiovascular system. Acta Pharmacol Sin. 2002;23(12):1142-1151.

26. Rai AK, Debetto P, Sala FD. Molecular regulation of cholesterol metabolism: HDL-based intervention through drugs and diet. Indian J Exp Biol. 2013;51(11):885-894.

27. Vasanthi R, ShriShriMal N, Das DK. Phytochemicals from plants to combat cardiovascular disease. Curr Med Chem. 2012;19 (14):2242-2251. doi:10.2174/092986712800229078

28. David B, Wolfender J-L, Dias DA. The pharmaceutical industry and natural products: historical status and new trends. Phytochem Rev. 2015;14(2):299-315. doi:10.1007/s11101-014-9367-z

29. Gu J, Gui Y, Chen L, Yuan G, Xu X. CVDHD: a cardiovascular disease herbal database for drug discovery and network pharmacology. J Cheminform. 2013;5(1):1-6. doi:10.1186/17582946-5-51

30. Du G, Sun L, Zhao R, et al. Polyphenols: potential source of drugs for the treatment of ischaemic heart disease. Pharmacol Ther. 2016;162:23-34. doi:10.1016/j.pharmthera.2016.04.008

31. Chang X, Zhang T, Zhang W, Zhao Z, Sun J. Natural drugs as a treatment strategy for cardiovascular disease through the regulation of oxidative stress. Oxid Med Cell Longev. 2020;2020:1-20. doi:10.1155/2020/5430407

32. Tesfaye BA, Berhe AH, Wondafrash DZ, Berhe DF. Cardioprotective effect of crude extract and solvent fractions of urtica simensis leaves on cyclophosphamide-induced myocardial injury in rats. $J$ Exp Pharmacol. 2021;13:147. doi:10.2147/JEP.S270038
33. Khan J, Deb PK, Priya S, et al. Dietary Flavonoids: Cardioprotective Potential with Antioxidant Effects and Their Pharmacokinetic, Toxicological and Therapeutic Concerns. Molecules. 2021;26 (13):4021. doi:10.3390/molecules26134021

34. Naithani R, Mehta RG, Shukla D, Chandersekera SN, Moriarty RM. Antiviral Activity of Phytochemicals: A Current Perspective. Dietary Components and Immune Function. 2010:421-468. doi:10.1007/978-1-60761-061-8 24.

35. Tresserra-Rimbau A, Arranz S, Vallverdu-Queralt A. New Insights into the Benefits of Polyphenols in Chronic Diseases. Oxidative Medicine and Cellular Longevity. 2017;2017:Article ID 1432071. doi:10.1155/2017/1432071

36. Michalska M, Gluba A, Mikhailidis DP, et al. The role of polyphenols in cardiovascular disease. Med Sci Monitor. 2010;16:5.

37. Said MM, Azab SS, Saeed NM, El-Demerdash E. Antifibrotic mechanism of pinocembrin: impact on oxidative stress, inflammation and TGF- $\beta$ /Smad inhibition in rats. Ann Hepatol. 2018;17 (2):307-317. doi:10.5604/01.3001.0010.8662

38. Alam M, Kauter K, Brown L. Naringin improves diet-induced cardiovascular dysfunction and obesity in high carbohydrate, high fat diet-fed rats. Nutrients. 2013;5(3):637-650. doi:10.3390/ nu5030637

39. Giudetti AM, Salzet M, Cassano T. Oxidative Stress in Aging Brain: Nutritional and Pharmacological Interventions for Neurodegenerative Disorders. Oxidative Medicine and Cellular Longevity. 2018;2018:Article ID 3416028. doi:10.1155/2018/ 3416028

40. Zhang S, Xu M, Zhang W, Liu C, Chen S. Natural polyphenols in metabolic syndrome: protective mechanisms and clinical applications. Int J Mol Sci. 2021;22(11):6110. doi:10.3390/ ijms22116110

41. Liu K, Luo M, Wei S. The bioprotective effects of polyphenols on metabolic syndrome against oxidative stress: evidences and perspectives. Oxid Med Cell Longev. 2019;2019:6713194. doi:10.1155/2019/6713194

42. Ninfali P, Mea G, Giorgini S, Rocchi M, Bacchiocca M. Antioxidant capacity of vegetables, spices and dressings relevant to nutrition. $\mathrm{Br} J$ Nutr. 2005;93(2):257-266. doi:10.1079/ bjn20041327

43. Mennen LI, Walker R, Bennetau-Pelissero C, Scalbert A. Risks and safety of polyphenol consumption. Am J Clin Nutr. 2005;81 (1):326S-329S. doi:10.1093/ajcn/81.1.326S

44. Ofosu FK, Daliri EB-M, Elahi F, Chelliah R, Lee B-H, Oh D-H. New insights on the use of polyphenols as natural preservatives and their emerging safety concerns. Front Sustain Food Syst. 2020;4:223. doi:10.3389/fsufs.2020.525810

45. Żwierełło W, Maruszewska A, Skórka-Majewicz M, et al. The influence of polyphenols on metabolic disorders caused by compounds released from plastics - Review. Chemosphere. 2020;240:124901. doi:10.1016/j.chemosphere.2019.124901

46. Ray S, Bagchi D, Lim PM, et al. Acute and long-term safety evaluation of a novel IH636 grape seed proanthocyanidin extract. Res Commun Mol Pathol Pharmacol. 2001;109(3-4):165-197.

47. Cerdá B, Cerón JJ, Tomás-Barberán FA, Espín JC. Repeated oral administration of high doses of the pomegranate ellagitannin punicalagin to rats for 37 days is not toxic. J Agric Food Chem. 2003;51(11):3493-3501. doi:10.1021/jf020842c

48. Gomes IBS, Porto ML, Santos MCLFS, et al. The protective effects of oral low-dose quercetin on diabetic nephropathy in hypercholesterolemic mice. Front Physiol. 2015;6:247. doi: $10.3389 /$ fphys.2015.00247

49. Catterall F, Souquet JM, Cheynier V, et al. Differential modulation of the genotoxicity of food carcinogens by naturally occurring monomeric and dimeric polyphenolics. Environ $\mathrm{Mol}$ Mutagen. 2000;35(2):86-98. doi:10.1002/(SICI)1098-2280(2000)35:2<86::AID-EM3>3.0.CO;2-B 
50. Lutz U, Lugli S, Bitsch A, Schlatter J, Lutz WK. Dose response for the stimulation of cell division by caffeic acid in forestomach and kidney of the male F344 rat. Toxicol Sci. 1997;39 (2):131-137. doi:10.1093/toxsci/39.2.131

51. Zhu B, Liehr JG. Quercetin increases the severity of estradiol-induced tumorigenesis in hamster kidney. Toxicol Appl Pharmacol. 1994;125(1):149-158. doi:10.1006/taap.1994.1059

52. Sakihama Y, Cohen MF, Grace SC, Yamasaki H. Plant phenolic antioxidant and prooxidant activities: phenolics-induced oxidative damage mediated by metals in plants. Toxicology. 2002;177 (1):67-80. doi:10.1016/S0300-483X(02)00196-8

53. Duo J, Ying -G-G, Wang G-W, Zhang L. Quercetin inhibits human breast cancer cell proliferation and induces apoptosis via Bcl-2 and Bax regulation. Mol Med Rep. 2012;5(6):1453-1456.

54. Temme E, Van Hoydonck P. Tea consumption and iron status. Eur J Clin Nutr. 2002;56(5):379-386. doi:10.1038/sj.ejen.1601309

55. Godos J, Marventano S, Mistretta A, Galvano F, Grosso G. Dietary sources of polyphenols in the Mediterranean healthy Eating, Aging and Lifestyle (MEAL) study cohort. Int $J$ Food Sci Nutr. 2017;68(6):750-756. doi:10.1080/09637486.201 7.1285870

56. Arts IC, Hollman PC. Polyphenols and disease risk in epidemiologic studies. Am J Clin Nutr. 2005;81(1):317S-325S. doi:10.1093/ajen/81.1.317S

57. Debnath S, Tejovathi R, Babu N, Kumar TH. An overview on food \& drug interactions. Pharm Times. 2017;49(4):9-15.

58. Hung CH, Chan SH, Chu PM, Tsai KL. Quercetin is a potent antiatherosclerotic compound by activation of SIRT1 signaling under oxLDL stimulation. Mol Nutr Food Res. 2015;59(10):1905-1917. doi:10.1002/mnfr.201500144

59. Basu A, Das AS, Majumder M, Mukhopadhyay R. Antiatherogenic roles of dietary flavonoids chrysin, quercetin, and luteolin. $J$ Cardiovasc Pharmacol. 2016;68(1):89-96. doi:10.1097/FJC.0000000000000380

60. Deng Y, Tu Y, Lao S, et al. The role and mechanism of citrus flavonoids in cardiovascular diseases prevention and treatment. Crit Rev Food Sci Nutr. 2021;10:1-24.

61. Bhaskar S, Kumar KS, Krishnan K, Antony H. Quercetin alleviates hypercholesterolemic diet induced inflammation during progression and regression of atherosclerosis in rabbits. Nutrition. 2013;29(1):219-229. doi:10.1016/j.nut.2012.01.019

62. Kleemann R, Verschuren L, Morrison M, et al. Antiinflammatory, anti-proliferative and anti-atherosclerotic effects of quercetin in human in vitro and in vivo models. Atherosclerosis. 2011;218(1):44-52. doi:10.1016/j.atherosclero sis.2011.04.023

63. Luo M, Tian R, Lu N. Quercetin inhibited endothelial dysfunction and atherosclerosis in apolipoprotein E-deficient mice: critical roles for NADPH oxidase and heme oxygenase-1. J Agric Food Chem. 2020;68(39):10875-10883. doi:10.1021/acs.jafc.0c03907

64. Zahedi M, Ghiasvand R, Feizi A, Asgari G, Darvish L. Does quercetin improve cardiovascular risk factors and inflammatory biomarkers in women with type 2 diabetes: a double-blind randomized controlled clinical trial. Int J Prev Med. 2013;4(7):777.

65. Ferenczyova K, Kalocayova B, Bartekova M. Potential implications of quercetin and its derivatives in cardioprotection. Int $\mathrm{J} \mathrm{Mol}$ Sci. 2020;21(5):1585. doi:10.3390/ijms21051585

66. Cancer IAfRo. Some chemicals that cause tumours of the kidney or urinary bladder in rodents and some other substances. IARC Monographs Eval Carcinogenic Risks Humans. 1999;73:13 $1-182$.

67. Manach C, Williamson G, Morand C, Scalbert A, Rémésy C. Bioavailability and bioefficacy of polyphenols in humans. I. Review of 97 bioavailability studies. Am J Clin Nutr. 2005;81 (1):230S-242S. doi:10.1093/ajcn/81.1.230S

68. Kelly GS. Quercetin. Alter Med Rev. 2011;16(2):172-195.
69. Daubney J. The Cardioprotective Mechanisms of Dietary Flavonoids. Nottingham Trent University (United Kingdom); 2015.

70. Wee SL. The Effects of Elicitors and Precursor on in vitro Cultures of Sauropus Androgynus for Sustainable Metabolite Production and Antioxidant Capacity Improvement. University of Nottingham; 2015.

71. Ganio MS, Armstrong LE, Johnson EC, et al. Effect of quercetin supplementation on maximal oxygen uptake in men and women. $J$ Sports Sci. 2010;28(2):201-208. doi:10.1080/02640410 903428558

72. Rezvan N, Moini A, Janani L, et al. Effects of quercetin on adiponectin-mediated insulin sensitivity in polycystic ovary syndrome: a randomized placebo-controlled double-blind clinical trial. Hormone Metabol Res. 2017;49(02):115-121.

73. Moghaddam RA, Akhtar M, Moghaddam AA, Najmi AK. Evaluation of cardioprotective effects of Camellia sinensis on isoproterenol induced myocardial infarction. Int $J$ Pharm Sci Res. 2013;4(3):1056.

74. Alam MA, Subhan N, Rahman MM, Uddin SJ, Reza HM, Sarker SD. Effect of citrus flavonoids, naringin and naringenin, on metabolic syndrome and their mechanisms of action. Advan Nutri. 2014;5(4):404-417. doi:10.3945/an.113.005603

75. Mahmoud AM, Hernandez Bautista RJ, Sandhu MA, Hussein OE. Beneficial effects of citrus flavonoids on cardiovascular and metabolic health. Oxid Med Cell Longev. 2019;2019. doi:10.1155/2019/5484138

76. Bharti S, Rani N, Krishnamurthy B, Arya DS. Preclinical evidence for the pharmacological actions of naringin: a review. Planta Med. 2014;80(06):437-451. doi:10.1055/s-0034-1368351

77. Raja kumar S, Mohd Ramli ES, Abdul Nasir NA, Ismail NHM, Mohd Fahami NA. Preventive effect of naringin on metabolic syndrome and its mechanism of action: a systematic review. Evid Based Compl Alter Med. 2019;2019:1-11. doi:10.1155/2019/9752826

78. Chen J, Guo R, Yan H, et al. Naringin inhibits ROS-activated MAPK pathway in high glucose-induced injuries in H9c2 cardiac cells. Basic Clin Pharmacol Toxicol. 2014;114(4):293-304. doi:10.1111/bcpt.12153

79. Dyck GJ, Raj P, Zieroth S, Dyck JR, Ezekowitz JA. The effects of resveratrol in patients with cardiovascular disease and heart failure: a narrative review. Int $J$ Mol Sci. 2019;20(4):904. doi:10.3390/ijms20040904

80. Riba A, Deres L, Sumegi B, Toth K, Szabados E. Cardioprotective effect of resveratrol in a postinfarction. Heart Fail Model. 2017;2017:6819281. doi:10.1155/2017/6819281

81. Zordoky BN, Robertson IM, Dyck JR. Preclinical and clinical evidence for the role of resveratrol in the treatment of cardiovascular diseases. Biochim Biophys Acta. 2015;1852(6):1155-1177. doi:10.1016/j.bbadis.2014.10.016

82. Bonnefont-Rousselot D. Resveratrol and cardiovascular diseases. Nutrients. 2016;8(5). doi:10.3390/nu8050250

83. Zhou Y, Little PJ, Xu S, Kamato D. Curcumin inhibits lysophosphatidic acid mediated MCP-1 expression via blocking ROCK signalling. Molecules. 2021;26(8):2320. doi:10.3390/molecules26 082320

84. Coban D, Milenkovic D, Chanet A, et al. Dietary curcumin inhibits atherosclerosis by affecting the expression of genes involved in leukocyte adhesion and transendothelial migration. Mol Nutr Food Res. 2012;56(8):1270-1281. doi:10.1002/mnfr.201100818

85. Barry SP, Townsend PA. What causes a broken heart-molecular insights into heart failure. Int Rev Cell Mol Biol. 2010;284:113-179.

86. Bai X-J, Hao J-T, Wang J, et al. Curcumin inhibits cardiac hypertrophy and improves cardiovascular function via enhanced $\mathrm{Na}+/ \mathrm{Ca} 2+$ exchanger expression after transverse abdominal aortic constriction in rats. Pharmacol Rep. 2018;70(1):60-68. doi:10.1016/j.pharep.2017.07.014 
87. Liu R, Zhang H, Yang J, Wang J, Liu J, Li C. Curcumin alleviates isoproterenol-induced cardiac hypertrophy and fibrosis through inhibition of autophagy and activation of mTOR. Eur Rev Med Pharmacol Sci. 2018;22(21):7500-7508.

88. Mohammed HS, Hosny EN, Khadrawy YA, et al. Protective effect of curcumin nanoparticles against cardiotoxicity induced by doxorubicin in rat. Biochimica et Biophysica Acta. 2020;1866 (5):165665. doi:10.1016/j.bbadis.2020.165665

89. Swamy AV, Gulliaya S, Thippeswamy A, Koti BC, Manjula DV. Cardioprotective effect of curcumin against doxorubicin-induced myocardial toxicity in albino rats. Indian J Pharmacol. 2012;44 (1):73. doi:10.4103/0253-7613.91871

90. He H, Shi M, Zeng X, et al. RETRACTED: Cardioprotective Effect of Salvianolic Acid B on Large Myocardial Infarction Mediated by Reversing Upregulation of Leptin, Endothelin Pathways, and Abnormal Expression of Serca2a, Phospholamban in Rats. Elsevier; 2008.

91. Sun A, Liu H, Wang S, et al. Salvianolic acid B suppresses maturation of human monocyte-derived dendritic cells by activating PPAR $\gamma . \quad B r \quad J$ Pharmacol. 2011;164(8):2042-2053. doi:10.1111/j.1476-5381.2011.01518.x

92. Wang S-B, Tian S, Yang F, Yang H-G, Yang X-Y, Du G-H. Cardioprotective effect of salvianolic acid A on isoproterenol-induced myocardial infarction in rats. Eur $J$ Pharmacol. 2009;615(1-3):125-132. doi:10.1016/j.ejphar.20 09.04.061

93. Bhardwaj P, Khanna D. Green tea catechins: defensive role in cardiovascular disorders. Chin J Nat Med. 2013;11(4):345-353. doi:10.1016/S1875-5364(13)60051-5

94. Anandh Babu P, Sabitha K, Shyamaladevi C. Green tea extract impedes dyslipidaemia and development of cardiac dysfunction in streptozotocin-diabetic rats. Clin Exp Pharmacol Physiol. 2006;33(12):1184-1189. doi:10.1111/j.1440-1681.2006.04509.x

95. Reygaert WC. Green tea catechins: their use in treating and preventing infectious diseases. Biomed Res Int. 2018;2018:1-9. doi:10.1155/2018/9105261

96. Reis JP, Loria CM, Steffen LM, et al. Coffee, decaffeinated coffee, caffeine, and tea consumption in young adulthood and atherosclerosis later in life: the CARDIA study. Arterioscler Thromb Vasc Biol. 2010;30(10):2059-2066. doi:10.1161/ ATVBAHA.110.208280

97. Bondonno NP, Bondonno CP, Blekkenhorst LC, et al. Flavonoidrich apple improves endothelial function in individuals at risk for cardiovascular disease: a randomized controlled clinical trial. $\mathrm{Mol}$ Nutr Food Res. 2018;62(3):1700674. doi:10.1002/mnfr.2017 00674

98. Lin X, Zhang I, Li A, et al. Cocoa flavanol intake and biomarkers for cardiometabolic health: a systematic review and meta-analysis of randomized controlled trials. J Nutr. 2016;146(11):2325-2333. doi:10.3945/jn.116.237644

99. Afshin A, Micha R, Khatibzadeh S, Mozaffarian D. Consumption of nuts and legumes and risk of incident ischemic heart disease, stroke, and diabetes: a systematic review and meta-analysis. $\mathrm{Am}$ J Clin Nutr. 2014;100(1):278-288. doi:10.3945/ajen.113.076901

100. Larsson SC, Åkesson A, Gigante B, Wolk A. Chocolate consumption and risk of myocardial infarction: a prospective study and meta-analysis. Heart. 2016;102(13):1017-1022. doi:10.1136/ heartjnl-2015-309203

101. Arab L, Liu W, Elashoff D. Green and black tea consumption and risk of stroke: a meta-analysis. Stroke. 2009;40(5):1786-1792. doi:10.1161/STROKEAHA.108.538470

102. Rather SA, Saravanan N. Protective effect of gallic acid on immobilization induced stress in encephalon and myocardium of male albino Wistar rats. Int J Nutri Pharmacol Neurol Dis. 2013;3 (3):269. doi:10.4103/2231-0738.114854
103. Kulkarni J, Swamy AV. Cardioprotective effect of gallic acid against doxorubicin-induced myocardial toxicity in albino rats. Ind J Health Sci Biomed Res. 2015;8(1):28.

104. Sathyapalan T, Aye M, Rigby A, et al. Soy isoflavones improve cardiovascular disease risk markers in women during the early menopause. Nutri Metabol Cardiovasc Dis. 2018;28(7):691-697. doi:10.1016/j.numecd.2018.03.007

105. Wenzel U, Fuchs D, Daniel H. Protective effects of soy-isoflavones in cardiovascular disease. Hämostaseologie. 2008;28(01/02):85-88. doi:10.1055/s-0037-1616927

106. Ko K-P. Isoflavones: chemistry, analysis, functions and effects on health and cancer. Asian Pac J Cancer Prev. 2014;15 (17):7001-7010. doi:10.7314/APJCP.2014.15.17.7001

107. Agunloye OM, Oboh G, Ademiluyi AO, et al. Cardio-protective and antioxidant properties of caffeic acid and chlorogenic acid: mechanistic role of angiotensin converting enzyme, cholinesterase and arginase activities in cyclosporine induced hypertensive rats. Biomed Pharmacother. 2019;109:450-458. doi:10.1016/j.biopha.2018.10.044

108. Murtaza G, Sajjad A, Mehmood Z, Shah SH, Siddiqi AR Possible molecular targets for therapeutic applications of caffeic acid phenethyl ester in inflammation and cancer. $J$ Food Drug Anal. 2015;23(1):11-18. doi:10.1016/j.jfda.2014.06.001

109. Silva H, Lopes NMF. Cardiovascular effects of caffeic acid and its derivatives: a comprehensive review. Front Physiol. 2020;11. doi:10.3389/fphys.2020.595516

110. Razani Z, Dastani M, Kazerani HR. Cardioprotective effects of pomegranate (Punica granatum) juice in patients with ischemic heart disease. Phytother Res. 2017;31(11):1731-1738. doi: $10.1002 /$ ptr.5901

111. Cao H, Xu H, Zhu G, Liu S. Isoquercetin ameliorated hypoxia/ reoxygenation-induced $\mathrm{H} 9 \mathrm{C} 2$ cardiomyocyte apoptosis via a mitochondrial-dependent pathway. Biomed Pharmacother. 2017;95:938-943. doi:10.1016/j.biopha.2017.08.128

112. Kong Q, Ma X, Wang C, et al. Patients with acute ischemic cerebrovascular disease with coronary artery stenosis have more diffused cervicocephalic atherosclerosis. J Atheroscler Thromb. 2019;26:47464.

113. Zhang L, Guo Z, Wang Y, Geng J, Han S. The protective effect of kaempferol on heart via the regulation of Nrf2, NF- $\kappa \beta$, and PI3K/ Akt/GSK-3 $\beta$ signaling pathways in isoproterenol-induced heart failure in diabetic rats. Drug Dev Res. 2019;80(3):294-309. doi:10.1002/ddr.21495

114. Durazzo A, Lucarini M, Santini A. Nutraceuticals in Human Health. Foods. 2020;9(3):370. doi:10.3390/foods9030370

115. Tresserra-Rimbau A, Rimm EB, Medina-Remón A, et al. Polyphenol intake and mortality risk: a re-analysis of the PREDIMED trial. $B M C$ Med. 2014;12:77. doi:10.1186/1741-7015-12-77

116. Tresserra-Rimbau A, Rimm EB, Medina-Remón A, et al. Inverse association between habitual polyphenol intake and incidence of cardiovascular events in the PREDIMED study. Nutr Metab Cardiovasc Dis. 2014;24(6):639-647. doi:10.1016/j.numecd.2013.12.014

117. Durazzo A, Lucarini M, Souto EB, et al. Polyphenols: a concise overview on the chemistry, occurrence, and human health. Phytother Res. 2019;33(9):2221-2243. doi:10.1002/ptr.6419

118. Singla RK, Dubey AK, Garg A, et al. Natural polyphenols: chemical classification, definition of classes, subcategories, and structures. J AOAC Int. 2019;102(5):1397-1400. doi:10.5740/ jaoacint.19-0133

119. Gormaz JG, Valls N, Sotomayor $\mathrm{C}$, Turner $\mathrm{T}$, Rodrigo $\mathrm{R}$. Potential role of polyphenols in the prevention of cardiovascular diseases: molecular bases. Curr Med Chem. 2016;23(2):115-128. doi:10.2174/0929867323666151127201732

120. Cory H, Passarelli S, Szeto J, Tamez M, Mattei J. The role of polyphenols in human health and food systems: a mini-review. Front Nutr. 2018;5:Article 87. doi:10.3389/fnut.2018.00087 


\section{Publish your work in this journal}

Drug Design, Development and Therapy is an international, peerreviewed open-access journal that spans the spectrum of drug design and development through to clinical applications. Clinical outcomes, patient safety, and programs for the development and effective, safe, and sustained use of medicines are a feature of the journal, which has also been accepted for indexing on PubMed Central. The manuscript management system is completely online and includes a very quick and fair peer-review system, which is all easy to use. Visit http://www. dovepress.com/testimonials.php to read real quotes from published authors. 